\title{
Perspectives on living with coeliac disease in remission Daily life experiences, symptoms and well- being
}

\author{
Lisa Ring Jacobsson \\ Department of Social- and Welfare Studies \\ Faculty of Health Sciences \\ Linköping University, Sweden

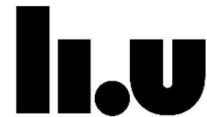 \\ LINKÖPING UNIVERSITY
}

Linköping 2015 
CLisa Ring Jacobsson, 2015

Cover picture: By my sister, Marie Björnhammer

Published articles have been reprinted with the permission of the copyright holder.

Printed in Sweden by LiU-Tryck, Linköping, Sweden, 2015

ISBN 978-91-7685-975-9

ISSN 0345-0082 
To my family

Bengt, Klara, Hannes, Erik, Anders and little Folke

"Tell me and I forget. Teach me and I remember. Involve me and I understand."

-Chinese adage 


\section{CONTENTS}

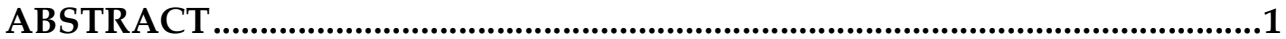

LIST OF PAPERS

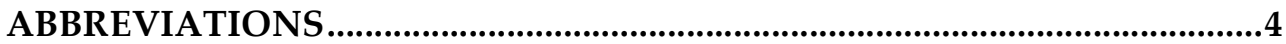

INTRODUCTION

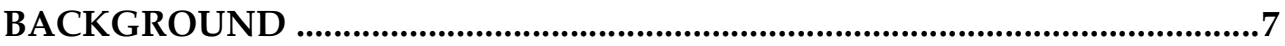

Chronic condition and chronic disease ………..........................................

Living with a chronic disease .........................................................................8

Sex and gender differences in health ...........................................................9

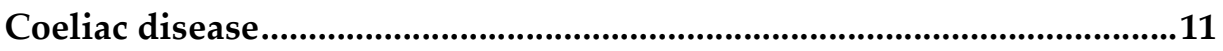

The challenges of treatment with a GFD ..........................................................13

Subjective well-being .........................................................................................14

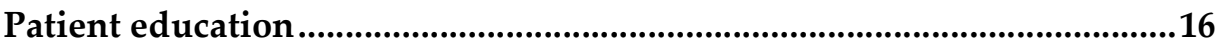

Problem-Based Learning................................................................................17

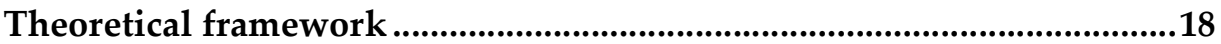

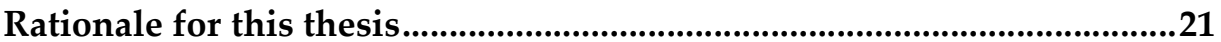

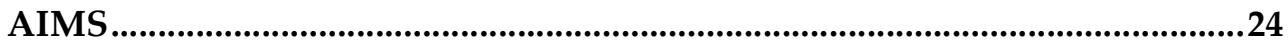

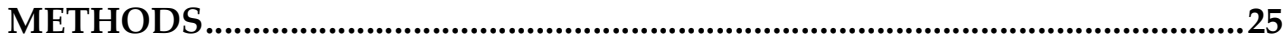

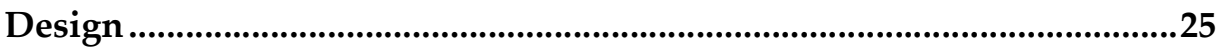

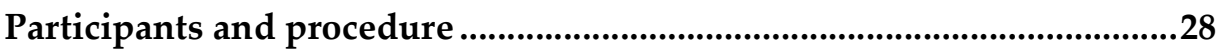

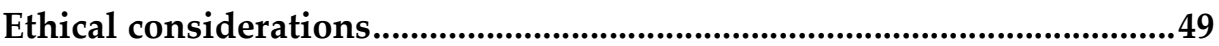

Establishing rigour in the thesis ...................................................................50

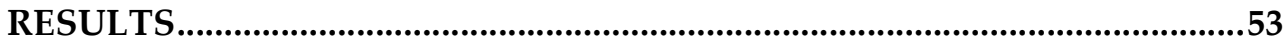

Daily life experiences of living with CD........................................................53

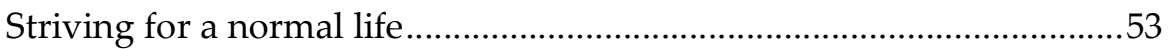

Conditions and measures facilitating a normal life ..................................54 


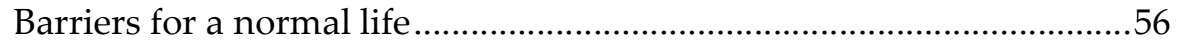

The influence of the PE program on women with CD.................................58

Influence on women's psychological well-being ...................................58

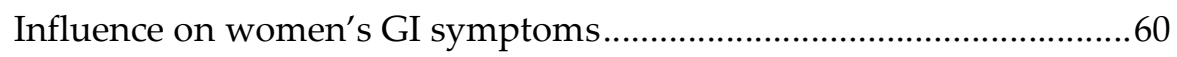

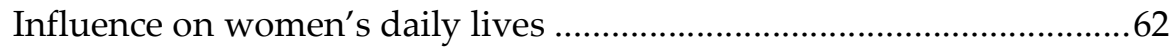

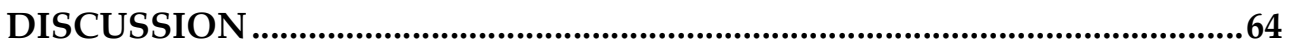

Methodological issues ....................................................................................74

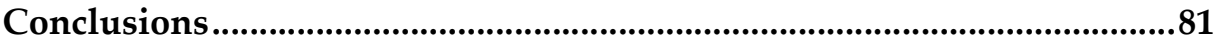

SVENSK SAMMANFATTNING SWEDISH SUMMARY .............................83

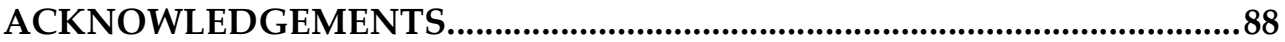

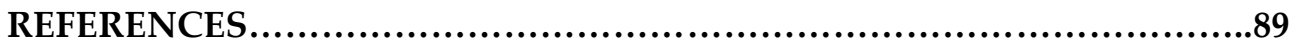




\title{
ABSTRACT
}

\section{Perspectives on living with coeliac disease in remission Daily life experiences, symptoms and well-being}

\begin{abstract}
Background and aims: Despite living with a gluten-free diet (GFD) Swedish women with coeliac disease $(C D)$ report a lower level of well-being than women without the disease and men with the disease. The all-embracing aim of the thesis was to study experiences of living with coeliac disease in remission and to discover whether a patient education intervention can influence the perceived health and daily life of women with coeliac disease.
\end{abstract}

Methods: Studies I-IV were based on the same sample, a total population of 106 women, $\geq 20$ years old, with confirmed CD, who had been treated with a GFD for a minimum of five years. From the total population of 106, 15 and 14 purposefully selected women were included in studies I and IV respectively, which had a phenomenological approach by which data was collected through recorded personal narrative interviews. The participants in studies II \& III, comprising the total sample of 106 women, were randomized to one of two groups: either to the intervention group $(n=54)$ that underwent a ten-session patient education (PE) program with problem based learning (PBL), or to a control group $(n=52)$ that received information regarding $C D$, which was sent to their home on a regular basis. Data was collected by self-administered questionnaires. Study V included 22 purposefully selected people (11 women and 11 men) with confirmed CD that had experienced any kind of residual discomfort despite treatment for at least five years with a GFD. Data was collected by recorded semi-structured interviews.

Well-being (II-III) was assessed at baseline and after 10 weeks in all patients and after six months in the intervention group using the Psychological General Well-Being index and the Gastrointestinal Symptom Rating Scale. The interviews (I \& IV), which were carried out before the start of the PE (I) and within two weeks of completion of the PE program and about three months after the first interview (IV), were analysed with descriptive phenomenology. The data from study $\mathrm{V}$ was analysed by content analysis.

Results: In the results, the experience of living with CD in remission was described by participants as a constant quest for a normal life (I, V). Three constituents representing conditions necessary to achieve a normalised lifeworld were described (I) as: being secure, being in control, and being seen and included. The balance of thoughts in relation to these constituents proved to be crucial for the individual woman's ability to experience a normal life, despite the disease. Participants described (V) conditions facilitating the opportunities to live a normal life, but also various barriers to reaching this goal.

The results from the PE based on PBL (II-III) showed that the PE improved psychological well-being (II) and GI (III) in women with CD to some extent, but not sufficiently as the 
improvement reached normative values for women only at 10 weeks regarding PGWB mean total index, and at no point in time regarding GSRS mean total index. The effect had waned at the follow-up six months after the intervention was completed as regards the women's psychological well-being. In coping with CD, it seems essential for women to interact with others with the same disease (IV). The interaction made women feel individually strengthened, and provided them with a broader perspective on life with CD. As a result, this strengthened their sense of self in relation to the disease. Knowledge given by other participants and experts could result in both relief and anxiety.

Conclusions: People with treated CD strive to live a normal life despite the disease. The ability to achieve this goal can be affected by factors such as residual symptoms and the fact that their concerns are not taken seriously by those around them (I,V). They are struggling daily in different ways to manage their $C D$ despite poor subjectively perceived health $(\mathrm{V})$. A PE with PBL can help women with CD to a higher degree of well-being (II, III). PE should specifically be offered to those women who fail to achieve a normalised lifeworld. However, intervention methods need to be refined in order to provide a more pronounced long-term effect. Future PE should take into account that in coping with $C D$, people need interaction with others with the same disease in order to acquire an overview regarding life with CD, develop a greater confidence, and dare to try new things in life (IV).

Key words: Chronic disease, illness experience, patient education, PBL, phenomenology, residual discomfort, well-being. 


\section{LIST OF PAPERS}

This thesis is based on the following papers, which will be referred to in the text by Roman numerals:

I. Jacobsson, L.R., Hallert, C., Milberg, A., Friedrichsen, M. Coeliac disease- Women's experiences in everyday life. Journal of Clinical Nursing 2012; 21: 3442-50.

II. Jacobsson, L.R., Friedrichsen, M., Göransson, A., Hallert, C. Does a Coeliac School Increase Psychological Well-being in Women Suffering from Coeliac Disease, Living on a Gluten-free Diet? Journal of Clinical Nursing 2011; 21: 766-75.

III. Jacobsson, L.R., Friedrichsen, M., Göransson, A., Hallert, C. Impact of an Active Patient Education program on Gastrointestinal Symptoms in Women with Celiac Disease Following a Gluten-free Diet: Randomized Controlled Trial. Gastroenterology Nursing 2012; 35: 200-206.

IV. Jacobsson, L.R., Milberg, A., Hjelm, K., Friedrichsen, M. Gaining perspective on own illness - The lived experiences of a patient education program for women with treated coeliac disease. Accepted for publication in Journal of Clinical Nursing (2015).

V. Jacobsson, L.R., Milberg, A., Hjelm, K., Friedrichsen, M. Experiences, own management and beliefs regarding residual symptoms among people with coeliac disease

Reprints were made with kind permission from the publishers 


\section{ABBREVIATIONS}

$\begin{array}{ll}\text { CA } & \text { Content Analysis } \\ \text { GD } & \text { Coeliac Disease } \\ \text { GFD } & \text { Gluten-free } \\ \text { GI } & \text { Gastrointestinal } \\ \text { GSRS } & \text { Gastrointestinal Symptom Rating Scale } \\ \text { LOC } & \text { Locus Of Control } \\ \text { PBL } & \text { Problem-Based Learning } \\ \text { PE } & \text { Patient Education } \\ \text { PGWB } & \text { Psychological General Well-Being index } \\ \text { QoL } & \text { Quality of Life } \\ \text { HLA } & \text { Human Leucocyte Antigen } \\ \text { HRQoL } & \text { Health-Related Quality of Life }\end{array}$




\section{INTRODUCTION}

This thesis begins with the understanding that there are many women with $\mathrm{CD}$ who are not doing well despite prolonged treatment. $\mathrm{CD}$, with a prevalence of approximately $1 \%$, is one of the most common lifelong disorders in Europe [1], and the most common food intolerance in the general Western population [2]. Healthcare assumes that people suffering from $C D$ who keep strictly to a GFD are considered to experience a significant symptomatic improvement in a short period of time [3]. However, they often perceive residual symptoms of various kinds [4-7]. Furthermore, people with treated $\mathrm{CD}$, particularly women, experience a lower level of quality of life (QoL) compared with non-coeliac controls [8-11] which is suggested to be closely associated with the perceived disease burden [12].

An individual's beliefs, which are based on the knowledge the person possesses [13], can affect a person's health status [14] and influence self-care measures [15]. Women suffering from CD consistently report more concerns than men related to the disorder and its management and have also stated a need to gain more knowledge $[12,16]$. However, people with CD in Sweden are often left to their fate after diagnosis and have no natural contact with health services [17]. For this reason, we do not know much about symptom experiences in people with treated $C D$, nor how it is to live with $C D$ as a woman. 
Previous research has shown that PE can help people with chronic diseases in the self-management of their disease so that they understand how to live in order to feel as good as possible [18]. Furthermore, PE can lead to improved QoL [19] and reduced symptom burden, and can affect a person's illness beliefs [20]. However, evidence-based PE for people with CD in Sweden is uncommon. There is some evidence that PE using the pedagogy of PBL is effective in chronic disease management [21], but this approach has never been tried on people with CD.

The occupational area of nursing involves a focus on human beings who have unmet needs related to their health or illness status. Nurses provide support in meeting these needs by enhancing adaptation capacity, developing self-care abilities, and promoting health and well-being [22]. An important role in nursing is to take part in PE. $[23,24]$.

With these perspectives in mind, it seems of interest to explore experiences and beliefs concerning residual symptoms in individuals with treated CD, and to consider how these people deal with these inconveniences. It is also of interest to gain a deeper understanding of how women with CD in Sweden experience their daily life, and to investigate whether PE with PBL is an effective way to satisfy their knowledge needs in order to support and encourage possible facilitating changes in their lifestyles, helping them to master the disease situation and thereby experience increased well-being. 


\section{BACKGROUND}

\section{Chronic condition and chronic disease}

In order to understand the context for the individuals participating in the studies in this thesis it is important to identify some of the central concepts that the thesis will use.

The first concept is "chronic condition", which is defined as a disability or disease conditions which people live with for a long time. The global healthcare challenge of this century is the dramatic increase in people suffering from chronic conditions [25]. After a diagnosis and necessary treatment, patients are often told that they should be able to live a normal life if they follow medical advice [26].

"Chronic disease", on the other hand, is a concept included as a subset of chronic conditions and refers to a specific medical diagnosis [27] that lasts longer than three months. WHO (2014) and the European Commission (2014) define chronic diseases as illnesses with a slow disease progression, often with gradual deterioration $[28,29]$. Chronic diseases are incurable, but not necessarily life-threatening/nor self-limiting, although, they cause a strain on the individual, their families, and on communities [30]. Chronic diseases may contribute to a reduced physical function, restriction of daily activities, increased independence, emotional distress, pain and changed self-identity. 
Chronic diseases thus have great influence on all aspects of a person's life, influencing physical, psychological, social and vocational functioning [31].

\section{Living with a chronic disease}

According to Charmaz (1983), living with a chronic disease involves a loss of self. The former self-image crumbles away without being replaced by an equally valued one. Individuals can experience diminished control over their lives and futures, and commonly they lose not only their self-esteem, but also their self-identity. Various sources of suffering, caused by a chronic disease, produce loss of self, for instance when the disease intrudes in a way that imposes restrictions in life [32]. Experienced illness intrusion is only partially related to the severity of the physical illness [33], but is influenced by a variety of psychosocial variables that are modifiable.

Some people are better equipped to cope with disruptions to life caused by disease, or to develop strategies to continue living an active life. Two important, but also related, psychosocial variables in this context are coping and a health-related locus of control (LOC) [34]. Lazarus and Folkman [35] argue that stress, due to for example a chronic disease, is composed of three processes. Primary appraisal is the process of assessing whether the stress shall be perceived as a threat or not. Secondary appraisal is the process that brings to mind a potential response to the threat. Coping is the process of carrying out this response. Active coping strategies, such as solving problems that occur and seeking social support can for instance help people with chronic diseases to maintain health-related quality of life (HRQoL) and mental health [36]. 
Health-related LOC refers to the person's beliefs about the source of their illness and the degree to which they can have control over the development of the disease [37]. People with a high internal LOC believe that their own health is mostly determined by their personal choices and actions. High external LOC in chance means that people believe that their health outcomes are mostly determined by chance or luck. People with a high external LOC believe that their health outcomes are determined by other people, for example health care providers [38]. Internal LOC is associated with more active coping patterns in people living with chronic diseases [39].

It is suggested that the signs of poor well-being should not be ascribed to CD itself, but to complications in adjusting to the nature of the disorder $[40,41]$. Inconveniences of various kinds, in relation to having CD and GFD, have been found to be more pronounced in women than in men [42-44].

\section{Sex and gender differences in health}

The concepts of sex and gender are used inconsistently and interchangeably in health care research. There is a distinction between sex, referring to biological femaleness respectively maleness, and gender, referring to social expectations [45]. However, the concept of "gender" involves more than the purely biological differences that exist between men and women. According to WHO:s definition, women and men differ in terms of biological make-up, but also regarding power, status, norms and roles in society. Gender norms and roles have an impact on person's susceptibility to various health conditions/diseases and by that influence individuals possibilities to 
experience good health and wellbeing [46]. Gender is not something a person 'is' or 'has', but is something that is always enacted in sickness and in health [47].

Women and men have different sensitivity to diseases and this can be explained by both sex and gender, but this difference is not well understood [48,49]. Sex-specific differences, i.e. biological genomic variations, are of importance [50]. Another explanation is that humans create genderdifferentiated environments [51]. In developed countries, the prevailing gender disparities in health care are that; women live longer than men, but they are more ill, report higher rates of morbidity and disability and also use more health care facilities than men [52].

Symptoms and experiences of ambiguous chronic illness in women might also be influenced by norms regarding gender $[53,54]$ and sometimes trivialized by health care providers as being psychosomatic in nature [55], even for people living with a chronic bowel disease [47].

Previous CD studies have repeatedly observed gender differences regarding symptoms and perceived disease burden $[42,56]$. According to Smirthwaite (2007) the knowledge about women's health and diseases is inadequate. This thesis should be seen as an addition to the knowledge about women experience of a chronic disease. 


\section{Coeliac disease}

$\mathrm{CD}$, also called coeliac sprue and gluten-sensitive enteropathy, is a multifactor autoimmune disorder in genetically susceptible people [57]. The disease is characterized by malabsorption resulting from inflammatory damage to the mucosa of the small intestine due to ingestion of wheat gluten or related rye and barley proteins $[57,58]$. CD was long regarded as a gastrointestinal (GI) disorder of childhood, but is now more frequently diagnosed in adults than in children. It is considered to be a chronic systemic disease [57] that meets the criteria of a true autoimmune disease [59]. Predisposing genes and ingestion of gluten are both crucial for the development of $\mathrm{CD}$, but most of the human leucocyte antigen (HLA)-DQ2 / DQ8 carriers (around 30\% of the population) who are exposed to gluten (>99\% of the population) do not develop CD. In fact only approximately $1 \%$ of the population [59], of which two thirds are women [60], develops $\mathrm{CD}$, indicating that environmental factors play a decisive role [59]. Many different environmental factors, apart from gluten, have been discussed, such as vitamin D and season of birth [61,62]. Above all, the early life factors that affect the intestinal environment, such as breastfeeding and infections, have recently attracted great interest [63].

$\mathrm{CD}$ is one of the most common immune-related diseases [64], but it is difficult to estimate its true prevalence because many adult carriers have atypical symptoms [65], or no symptoms at all, so-called silent CD (Sharma et al., 2013). The widespread dissemination of $\mathrm{CD}$ is not surprising since its causal factors (HLA predisposing genotypes and consumption of cereals containing gluten) shows a worldwide distribution [1], and as is the case also for many other 
diseases with autoimmune background, the true incidence seems to have increased [1,66] both in children and adults of various ethnic origins [59]. In Japan, Korea, Indonesia and the Philippines, CD is rare, probably as a result of low consumption of wheat, but also a low frequency of HLA-DQ2 [58] .

CD has a wide spectrum of GI and extra- intestinal manifestations. In adults, iron-deficiency anaemia and diarrhoea are common features. Less common features can be divided into: a) general features, such as short stature; b) GI features, such as recurrent abdominal pain and steatorrhea; and c) extraintestinal features such as nutritional deficiencies, osteoporosis, malignancy, alopecia, anxiety \& depression, dermatitis herpetiformis, neurological symptoms etc. [67]. A high degree of suspicion is required to make the correct diagnosis as more than $40 \%$ of people with CD present with symptoms other than GI ones, such as hypothyroidism, diabetes, anaemia, infertility etc. [68]. The new diagnostic tools, according to the latest guidelines, have facilitated the diagnosis significantly and include serologic tests for antibodies against tissue transglutaminase and deamidated gliadin peptide. Also, tests for coeliac-permissive HLA-DQ2 and HLA-DQ8 molecules are used. A histopathological duodenal biopsy is also included in the diagnostic proceedings [58]. Also, approaches that imply non-invasive diagnostic strategies have been scrutinized [69].

Adults with both symptom- and screen-detected CD are considered to experience an improved state of health and QoL with a GFD [70] as the damage to the intestine is relieved [71] and associated symptoms are reversed. Moreover, a GFD decreases the risk of malignancy and mortality [58]. The 
phenomenon of remission in $\mathrm{CD}$ however, implies the disappearance of $\mathrm{CD}$ antibody levels in the blood [72]. An abundance of food contains gluten, but it must be clearly labelled by law [73]. New pharmacological treatment, based on current knowledge regarding the disease pathogenesis, is under active investigation $[59,74]$. The sensitivity to gluten varies, but regardless of that it is important to exclude all dietary gluten [73].

In the current situation, we thus know what treatment heals the damage to the intestine when $\mathrm{CD}$ occurs, but we know less about what it is like to live with this disease. The impact of $\mathrm{CD}$ on individuals is generally poorly explored from a nursing perspective and it is therefore considered an interesting area for this thesis.

\section{The challenges of treatment with a GFD}

CD is currently treated with a lifelong GFD, which implies avoiding storage proteins found in wheat, barley and rye, but also hybrids of these grains, such as triticale and kamut [75]. This diet is composed of a combination of naturally GF products, i.e. products that do not include gluten-containing cereals, and cereal-based GF substitutes, i.e. ingredients from such cereals where gluten is removed, such as bread, cookies, pasta, etc. [76]. The diet and the GF products are often low in B vitamins, calcium, vitamin D, zinc, iron, magnesium, and fibre. It is rare that GF products are fortified, which increase the risk of nutrient deficiencies [75], and worldwide there is an ongoing debate regarding an accepted definition of GF [77]. 
Following a GFD is difficult for many people. Besides various practical constraints, such as generally poor availability of GF food [78] and high costs [58] etc., research has revealed negative psychosocial effects deriving from this form of dietary self-management, with women reporting greater emotional responses to a GFD [79]. CD can be viewed as a stigmatizing condition. Normative social rules in relation to meals and eating are not followed [80], and experiences of being different are widespread [81]. Many people with CD do not believe they can live as normal individuals in situations that include food, as the treatment cannot be readily concealed in many social contexts, leading to unwanted attention. In practice, avoidance of food can be considered as rudeness towards the person who prepared the food, and as a guest the person with $\mathrm{CD}$ can feel the need to explain in order to save face [80]. People with CD worry about not being believed or being identified as "picky" types, but also worry about becoming contaminated by gluten [82]. Food-related anxiety has been shown to be greater in women with CD than in men [56].

\section{Subjective well-being}

Subjective well-being in persons suffering from CD has been identified as a great problem in many studies $[11,83]$. Subjective well-being in the terms of Diener (2006.pp.400), is "an umbrella term for the different values people make regarding their lives, the events happening to them, their bodies and minds, and the circumstances in which they live". Such values are subjective, because they are experienced internally; they constitute aspects of well-being in the sense that they relate to the pleasantness and desirability or otherwise 
particular states and aspects of people's lives [84]. Subjective assessment offers perspectives beyond the traditional biomedical markers and is a necessary complement to objective evidence of disease [85]. Self-rated health has been shown to be consistent with more objective health status measures in the general population [86], and because of its predictable functions, self-rated health is frequently used as an outcome measure in health service interventions [37]. This can be considered as indicating health authorities' trust in individuals' own ability to report symptoms in a reliable and, for healthcare services, useful way.

All symptomatic conditions affect a person's well-being significantly, including the potential to function in daily life. The concept of "well-being" can be described in terms of being well, healthy, contented etc. and it denotes a state where the individual's basic needs are satisfied. Well-being also refers to a person's state of health, in the sense of including not only the absence of disease, but also the quality of health which the person experiences. The meaning of the concept of well-being also varies depending on where the person is living, and can then also be explained by factors such as income, religion etc. [87]; i.e. the types of factor that we in Sweden might very well connect with the concept of life-satisfaction.

In this thesis the concept of well-being refers to the person's state of health, in the sense of including the quality of health that person experiences. A person's quality of health is closely related to the concept of QoL, which some authors claim can be measured objectively, although other authors argue that it can only be measured by the individual living that life [88]. Statistic demonstrating 
that people with $\mathrm{CD}$ experience lower well-being than healthy individuals is the fact that up to $30 \%$ [7] of people with CD, despite remission with GFD, suffer from residual discomfort of various kinds [4-7]. A Swedish study even shows that individuals diagnosed with $\mathrm{CD}$ have a higher suicide risk than the general population, especially during the first year after diagnosis [89]. Furthermore, people with treated CD, particularly women, experience a lower level of QoL than non-coeliac controls of the same age $[9,44,90,91]$, and it has also been found that women with $\mathrm{CD}$ also use annual health care services more often than female controls, due to related mental and behavioural disorders, diseases of the digestive system, and diseases of the musculoskeletal system and connective tissues [92].

\section{Patient education}

Patient education is an important strategy within health care, and includes all forms of planned educational activities undertaken to improve patients' health behaviour and status $[93,94]$. Increased knowledge can lead to an improved HRQoL [95]. The current health care policy in Sweden emphasises selfmanagement and support of the patient's participation as ways of improving patient outcomes and reducing healthcare costs [25]. The main objective of PE is to motivate the person to adhere to the prescribed treatment and adopt a lifestyle that promotes health [96]. Unfortunately, educational efforts performed by nurses are not always evidenced-based [97].

PE is not just a way for individuals to acquire knowledge. People need to see the benefits of lifestyle changes, and the knowledge must also simplify and 
improve life for them [98]. Knowledge alone is thus limited to inducing a person to implement changes in self-care management, unless the person feels motivated. Merely knowing a blood sugar value does not benefit the individual if he or she does not understand the significance of this particular value $[98,99]$. This implies that theoretical knowledge does not automatically mean that the person knows what action should be taken. Therefore, it is necessary to start any educational effort directed towards a specific group of people by investigating their daily life experiences and their needs of knowledge in order to be able to develop an intervention that individuals experience as motivating. This action has, to our knowledge, never before been performed with regard to women with CD.

There are currently many different educational models for PE. One of them is PBL, which is one way of bringing together education, counselling and behaviour intervention in order to support self-management in people with chronic diseases. Despite a limited number of attempts to use this method, there is some evidence of its effectiveness in promoting self-management with individuals suffering from diabetes, arthritis, asthma and coronary artery disease [21]. There are no studies of the $\mathrm{CD}$ population using this approach. These factors combined settled the choice of using PBL as a pedagogical model for the PE intervention in this thesis.

\section{Problem-Based Learning}

PBL was first applied in the curricula of McMaster University, Hamilton and Limburg University, Maastricht [100]. PBL is different from the passive 
memorization of knowledge that occurs in traditional lecture and reading situations [101]. The PBL approach can be seen as a way of learning rather than a way of teaching [100]. Three essential characteristics distinguish the process of PBL. The first is that learning is based on a problem, a question or a puzzle that the learner wishes to solve. Secondly, a student-centred nature is adopted, with an emphasis on self-directed learning. With the given problem as a start, the learners are responsible themselves for deciding what they want to know and what they need to learn. Thirdly, the method involves working in small groups (5-10 people) [102]. Small groups promote opportunities for the participants to exchange personal experiences and knowledge in relation to the problem to be solved, and this facilitates the problem-solving process [101]. Using the problem-solving process, gaps in knowledge and lifestyle can be identified, leading to a change [103]. The PBL approach strives to promote independence, functional knowledge, critical thinking and lifelong learning [101]. Problems in PBL are always based on situations drawn from everyday life, and the problem-solving process facilitates the possibility to apply new knowledge in real situations [104].

\section{Theoretical framework}

The standpoint of this thesis is nursing theory focusing on the perspective of being a human in the transition process with health problems, with adjustment and self-care influences. Nursing care aims to help people who have unmet needs related to their health or to a disease, to meet those needs by increasing adaptability, to develop self-care skills, and to promote their own health and well-being [22]. Living with a chronic illness such as CD, 
means coping with and adjusting to physical, psychological, social and spiritual losses, as described in the "transitions theory" by Meleis (2010). A transition denotes a change in life, such as in health status. It includes both the process and the outcome, of complex interactions between the person and the environment [105]. The main characteristics of a transition are: process, disconnectedness, patterns of response and conditions [106]. The transition processes occur over time and have a sense of flow, in contrast to a change, which tends to be abrupt [107]. The process includes an ending of the old situation, a start of the transition, a period of distress, and is leading to a new beginning in a partly new situation. Disconnectedness refers to a disruption of the linkages on which the person's feelings of confidence depends [106], and patterns of response arise out of the persons observable and non-observable behaviours during the transition process, and reflects both intra psychic patterns and processes, such as changes in self- concept, anxiety etc., but also process indicators such as if a person is coping with the new situation [106,108]. The conditions in the process, such as the person's beliefs, attitudes, socio-economic status, knowledge etc. can facilitate, but also inhibit, a healthy transition [108]. To be in a transition the person has to be aware of the changes that are occurring [106]. The participants in this thesis could be seen as they are in a transition.

A framework for viewing nursing practice, education and management is the self-care deficit theory, developed by Orem [111]. Self-care is all the activities individuals initiate and perform on their own behalf in order to maintain their life, health and well-being. Effective performance in response to the requisites, called therapeutic self-care demands, enables people to become involved in 
their disease management and learn to live with their health problems [112]. The nursing process involves determining a person's self-care ability, and based on that, deciding the required level of nursing: wholly compensatory, partly compensatory or supportive/educative [111]. According to Meleis (2011), caring for people involves supporting individuals to handle their chronic disease, and thereby master their own self-care demands [22]. This implies that nurses, in their ambition to support people with chronic diseases, should not only focus on symptom control, but instead should view this as a transitional experience [107]. Consequently, there is a need to shift from a disease-oriented perspective to a health- promoting one (Whitehead et al., 2008) with respect to patient autonomy (Friberg et al., 2012), and selfmanagement abilities (Redman, 2008). This can be accomplished with various nursing interventions, such as PE. A significant pedagogical/tutorial role in PE is played by nurses $[23,24,97]$.

Participation is a central concept in Orem's theory, and the relationship between the individual in need of care and the nurse is based on a balance between the individual's self-care needs and her self-care abilities. The nurse's role in this relationship, which requires partnership, is to act when and where the individual is unable to do so i.e. when a self-care deficit occurs [111].

People may have varying abilities to meet the demands placed on them in carrying out self-care activities, and these demands increase when a person's health is affected by illness. Chronic diseases, for example, may require an individual to take further measures to look after him/her-self or seek assistance from others. Orem believes that nurses can perform a wide variety 
of activities to help patients to move towards a position where they can take a more active and decisive role in their care. Also, Orem argues that one important nursing intervention opportunity is teaching [111]. The belief in people's ability and willingness to learn represented by Orem's self-care deficit theory of nursing, fits well with the ideas highlighted in PBL. Both share the view that people have the potential and the willingness to develop practical as well as intellectual skills $[101,111]$. Furthermore, both stress that the "object for learning" must be put forward in an appropriate context, which means it must be translated into a form that can be utilised in practice $[101,112]$.

The treatment for CD is lifelong and implies following a GFD. People with CD in Sweden are often left on their own, to manage their self-care, after diagnosis [17]. The need for care and support is not static for individuals with a chronic disease such as $\mathrm{CD}$, but varies over time. In addition, this disease is rare enough that many people do not have anyone with whom they can discuss their daily life experiences regarding CD. Factors such as these can result in the total demand placed upon the individual exceeding the person's ability to meet it.

\section{Rationale for this thesis}

$\mathrm{CD}$ is a chronic disease that in addition to being incurable also implies a challenging treatment, often causes confusion in the environment, and frequently implies a dramatic change in routine activities. Previous research has shown that $C D$ has negative social effects and causes impaired HRQoL 
$[80,83]$. It is also known from earlier research that many people with CD experience various kinds of inconveniences in relation to having $\mathrm{CD}$, even after several years of treatment $[5,113]$. Despite this, people with CD get little attention within the health care system, and in Sweden it is customary that this patient group does not receive any further routine health care follow-up after diagnosis [17].

$\mathrm{CD}$ affects women to a greater extent than men [114], and studies claim that women, for unknown reasons, are doing worse than men during treatment $[42,91]$. Hence, although some studies have contributed data in relation to differences between women's and men's experiences of having CD [115] and being treated with GFD [116] as well as the inconveniences and obstacles in connection with the disease [56], few studies have exclusively focused on women's own perspectives of living with the disease. Therefore it would be of interest to explore, in more depth, what colours women's life with this disease.

Patient education with PBL has been described as a way of combining education, counselling and also behaviour intervention, and has previously been tested with good results in the management of several chronic diseases [21]. However, to our knowledge, this has never been tested regarding individuals with $\mathrm{CD}$, so such a study would therefore be an interesting contribution to both researches in PBL as well as CD. Furthermore, there is a need for reducing the knowledge gap regarding knowledge about own management of residual symptoms among individuals with treated $C D$, as well as their beliefs concerning the underlying causes of these symptoms, which may guide a person's disease management behavior [15]. Therefore, 
this thesis aims to increase the knowledge about how women with treated CD experience everyday life, their symptom experiences, and their beliefs about the underlying causes of residual discomfort. This will be accomplished by including men in one of the studies in the thesis, and contrasting the gender groups' experiences in the field to shed further light on the women's situation. Furthermore, this thesis aims to evaluate whether a PE programme would facilitate life for women with $C D$, and thereby gain a deeper understanding regarding how a PE for this group should be designed. These various actions may be of importance in increasing knowledge about the living conditions for those in society living with $\mathrm{CD}$, which ultimately would lead to implementation of PE and support for these individuals, and changes in follow-up routines. 


\section{AIMS}

The all-embracing aim of the thesis was to study experiences of living with coeliac disease in remission and to discover whether a patient education intervention can influence the perceived health and daily life of women with coeliac disease.

\section{The specific aims were as follows:}

\section{Study I}

To describe the lived experience of being a woman with coeliac disease in Sweden.

\section{Studies II \& III}

To evaluate the effect of a patient education programme using problem-based learning versus participation in a waiting-list control group that received written information corresponding to the information these patients meet in contact with health care, on psychological well-being (II), and gastrointestinal symptoms (III) for women with coeliac disease in remission.

\section{Study IV}

To explore the lived experiences of women with coeliac disease after attending a patient education program, in order to gain a broader perspective on its influence.

\section{Study V}

To explore experiences and beliefs concerning residual symptoms that persist despite following a gluten-free diet in women and men, with a focus on causes and management. 


\section{METHODS}

\section{Design}

Both inductive and deductive scientific methodologies have been used to address the aims of this thesis. In research it is useful to combine qualitative and quantitative methods in a complementary manner in order to provide a well-integrated picture of the situation. This is one possible way to strengthen a project [117].

Studies I and IV are interview studies that use a phenomenological approach. Studies II and III are based on the same intervention, a PE intervention with PBL, performed as a randomized controlled trial. Study V is a qualitative descriptive study (Table 1). 
Table 1. Overview of participants, data collection and analysis in papers I V.

\begin{tabular}{|c|c|c|c|}
\hline Paper & Participants & $\begin{array}{l}\text { Method of data } \\
\text { collection }\end{array}$ & $\begin{array}{l}\text { Method of data } \\
\text { analysis }\end{array}$ \\
\hline $\mathrm{I}$ & $\mathrm{n}=15$ & Individual narrative interviews & $\begin{array}{l}\text { A phenomenological } \\
\text { analysis }\end{array}$ \\
\hline II & $\mathrm{n}=106$ & $\begin{array}{l}\text { Self-administered } \\
\text { questionnaires, PGWB and } \\
\text { GSRS }\end{array}$ & $\begin{array}{l}\text { ANOVA, t-test } \\
\text { statistics }\end{array}$ \\
\hline III & $n=106$ & $\begin{array}{l}\text { Self-administered } \\
\text { questionnaires, PGWB and } \\
\text { GSRS }\end{array}$ & $\begin{array}{l}\text { ANOVA, t-test } \\
\text { statistics }\end{array}$ \\
\hline IV & $\mathrm{n}=14$ & Individual narrative interviews & $\begin{array}{l}\text { A phenomenological } \\
\text { analysis }\end{array}$ \\
\hline $\mathrm{V}$ & $\mathrm{n}=22$ & $\begin{array}{l}\text { Recorded semi-structured } \\
\text { interviews }\end{array}$ & Content analysis \\
\hline
\end{tabular}

In total, 128 people were included in the different studies 


\section{Enrollment}

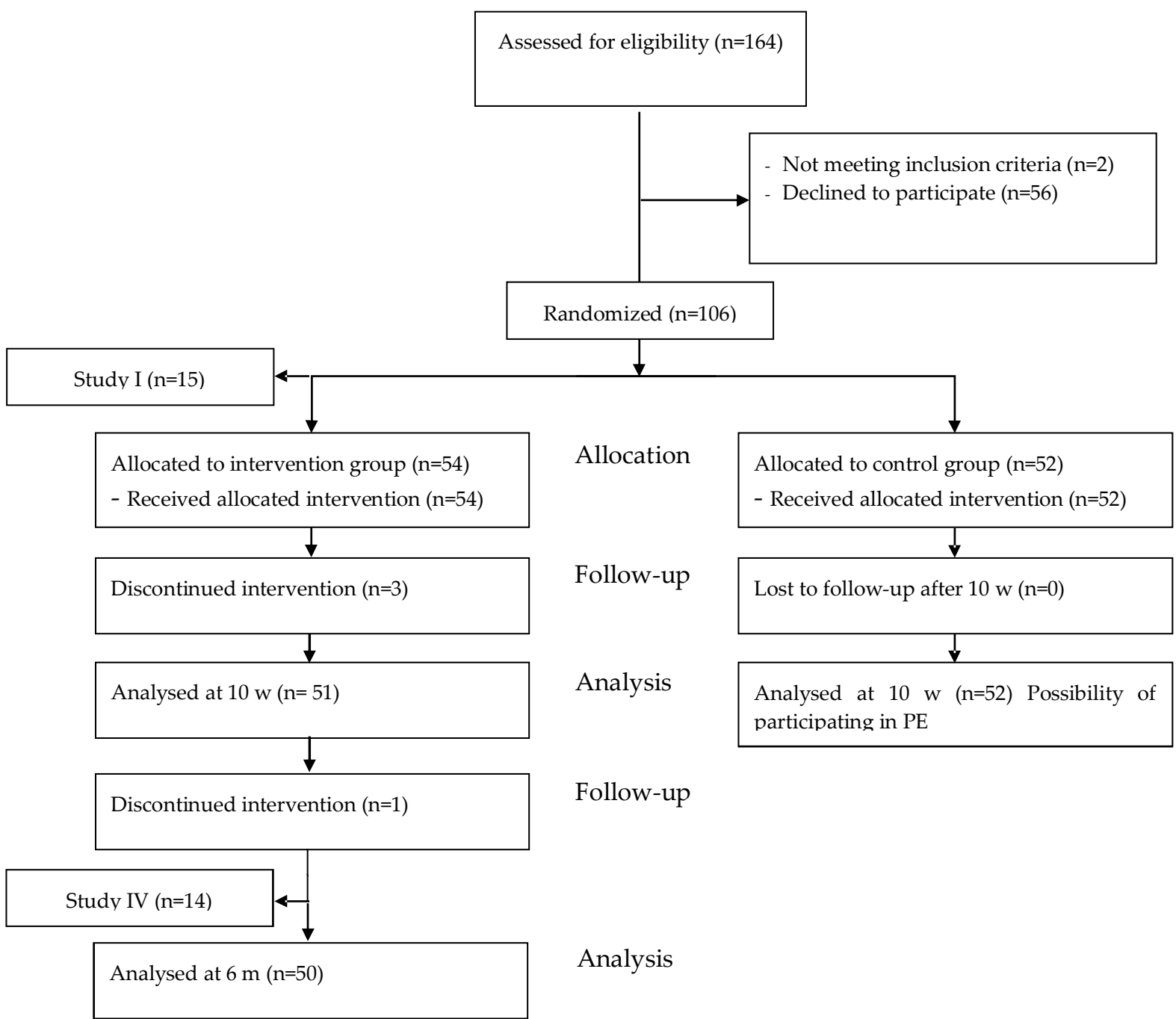

Fig 1. Flowchart of events in studies I-IV, from recruiting participants to study completion (CONSORT 2010 flow diagram). 


\section{Participants and procedure}

The studies included in this thesis purposely started with an interview study (I) to identify how women with $\mathrm{CD}$ experience daily life. This knowledge was then used in the development of the PE in Studies II-III. After completion of the intervention (II-III), participants were interviewed again (IV) to obtain complementary information regarding the influence of the PE. Study V gives a description of how residual discomfort in $\mathrm{CD}$, despite clinical remission, is expressed and managed by those affected, and what they believe their discomfort is caused by.

\section{Study I-IV}

All four studies were based on the same sample (Table 2), from a region in the south of Sweden. To find female candidates, dieticians working in hospitals in five Swedish cities were asked for help to identify potential participants through medical records. Additionally, advertisements in magazines for CD association members invited women to participate. Participants were invited, by postal mail, to an information meeting in one of the towns in question. At these meetings, verbal as well as written information was given regarding all parts of the study. A total of 106 women out of 164 assessed for eligibility, were enrolled (Fig 1).

The inclusion criteria were: Women aged 20 years or above with CD who had been treated with a GFD for a minimum of five years. The exclusion criterion was having a concomitant serious health disorder. Two women with other 
ongoing diseases (malignancy and Parkinson's disease), which might affect the results of the questionnaires and might also hinder their chances of fulfilling the entire PE program, were excluded from the study.

After obtaining written consent, randomization (II - III) was done according to place of residence, with consent forms used as lots. This was done in such a way that consent forms were placed into groups representing the cities the person who completed them came from; people belonging to one city constituted one group. Each city-group was mixed well by hand, and randomization was thereafter carried out for one heap of forms at a time by alternately sorting forms into the intervention group and to the control group. This procedure, performed by the author, resulted in 54 participants in the intervention group (divided into seven groups in the five towns) and 52 participants in the control group. Based on the total number of women randomized to the intervention group $(\mathrm{n}=54)$, fifteen women (2-4 individuals per city) were also asked to participate in the interview studies (I \& IV). These women were selected purposively; i.e. deliberately selected using a nonrandomized approach [117], to achieve heterogeneity with regard to years since diagnosis ( $\geq 5$ years), residence, age, civil status and education. All women who were asked to participate responded positively.

Three women in the intervention group did not complete the trial at the tenweek follow-up due to a workload situation (one person), lack of time (one person) or onset of another illness (one person), and one person failed to complete the questionnaire at the six-month follow-up (due to lack of time) within the intervention group. After ten weeks, the control group was offered 
participation in the same PE as the intervention group due to ethical reasons, and was therefore no longer included in the study. Twenty-eight women out of 52 accepted this offer. All control group members completed their questionnaires (PGWB index and GSRS scale) at the ten-week follow-up.

One of the women from the intervention group who had also agreed to participate in the interview studies (I \& IV) did not complete the trial and was therefore also excluded from study IV.

\section{Study V}

Participants (women and men) from the south of Sweden were recruited to this study using regional care databases representing one university hospital, one county hospital and four primary health care centrals. People with assured CD (International Classification of Diseases, ICD 10-code K90.0A) were sent an information letter and asked to participate. The letter clarified the purpose of the study and the criteria for participation, and also included an informed consent form and a postage-paid return envelope. Participants were selected in purpose [117] to obtain maximum variation regarding: age, number of years since diagnosis, residence, family circumstances, education and employment status. Individuals $(n=36)$ that returned the informed consent, and thus demonstrated interest in participating, were contacted by telephone. This was done to determine whether the person met the inclusion criteria i.e. had been living on a GFD $\geq 5$ years, was experiencing any kind of residual discomfort and spoke and understood Swedish. If these criteria were fulfilled an appointment for an interview was made. Twenty-two people were included in the study (Table 2). 
Table 2. Characteristics of women in the interview studies (I; $n=15$, IV; $\mathrm{n}=14$ ), and in the randomized control study (II-III); intervention group $(n=54)$; and control group $(n=52)$, and of women $(n=11)$ and men $(n=11)$ included in the interview study $\mathrm{V}$.

\begin{tabular}{|c|c|c|c|c|c|c|c|c|c|c|c|c|c|}
\hline \multirow[t]{2}{*}{ Group } & \multicolumn{2}{|c|}{ Age in years } & \multicolumn{2}{|c|}{$\begin{array}{c}\text { Time since } \\
\text { diagnosis } \\
\text { (years) }\end{array}$} & \multicolumn{3}{|c|}{ Civil status (n) } & \multicolumn{3}{|c|}{ Domicile (n) } & \multicolumn{3}{|c|}{ Education level (n) } \\
\hline & $\begin{array}{c}\text { Mean } \\
\text { (median) }\end{array}$ & Range & $\begin{array}{c}\text { Mean } \\
\text { (median) }\end{array}$ & Range & Married & Single & Widow & Town & Village & Rural & $\begin{array}{l}\text { Primary } \\
\end{array}$ & Secondary & Higher \\
\hline Study I & (67) & $30-75$ & (14.5) & $5-67$ & 10 & 3 & 2 & 13 & 1 & 1 & 5 & 8 & 2 \\
\hline $\begin{array}{l}\text { Intervention } \\
\text { Study II-III }\end{array}$ & 51.8 & $23-80$ & 14.9 & $5-67$ & 35 & 15 & 4 & 38 & 14 & 2 & 9 & 20 & 25 \\
\hline $\begin{array}{l}\text { Control } \\
\text { Study II-III }\end{array}$ & 53.6 & $23-74$ & 15.5 & $5-51$ & 39 & 10 & 3 & 26 & 20 & 6 & 8 & 17 & 27 \\
\hline Study IV & (66) & $30-75$ & (14) & $5-67$ & 10 & 3 & 1 & 12 & 1 & 1 & 5 & 8 & 1 \\
\hline Study V & & & & & & & & & & & & & \\
\hline Women & (48) & $32-64$ & (9) & $6-42$ & 8 & 3 & 0 & 5 & 1 & 5 & 1 & 6 & 4 \\
\hline Men & (54) & $33-63$ & (15) & 6-39 & 9 & 2 & 0 & 6 & 2 & 3 & 4 & 6 & 1 \\
\hline
\end{tabular}

In the next section, the data collection and data analysis in studies I \& IV will be presented. Thereafter, follows a description of the intervention, data collection and statistical analyses in studies II-III, and finally a description of the data collection and data analysis regarding study $\mathrm{V}$ is presented. 


\section{Studies I \& IV}

\section{Phenomenology}

Phenomenological research in general strives to clarify situations that people experience in their daily lives, i.e. to study specific phenomena of which the interviewee has first-hand experience and can describe how it actually took place (Giorgi and Giorgi in Smith, 2003). In studies I and IV of the current thesis, descriptive (eidetic) phenomenology has been used as the research approach. It was chosen because life experiences were the focus of this research, but this approach has also been demonstrated as useful in uncovering essences of phenomena that have not been completely conceptualized by prior research [118]. The central figure in phenomenology, Edmund Husserl (1859-1938), argued that the way that such phenomena appears in everyday life, the so-called lifeworld, constitutes valuable knowledge, and with a scientific approach the essential components, i.e. the essence, of the experience will emerge [119]. The essence of consciousness is intentionality, which implies that mental acts of all kinds are intentional, and thus they point to something or some object that is not consciousness itself [120]. Husserlian phenomenology emphasises the importance for the researcher of shedding all prior knowledge in order to grasp the essential lived experiences of those people studied [119]; i.e. one must be present at the "given" as it presents itself, without either adding or subtracting [121]. For this reason there was no prepared interview guide, other than the one opening question expressing the desire for a description of the lived experience of being a woman living with $\mathrm{CD}(\mathrm{I})$, and the wish for an account of whether the education program had influenced the participant's daily life, and if so, in 
what way (IV). The goal of the researcher is to achieve "transcendental subjectivity", which means that the impact on results derived from the researcher must be constantly assessed and influencing factors neutralized [119]. Within descriptive phenomenology, "bracketing" or "epoché" is proposed for this purpose; i.e. the researcher puts aside past knowledge about what is presently given so the attention can be directed to what is present [121]. For this thesis, the author's pre-understanding of the subject of CD was derived from occasional meetings with children and adolescents with $\mathrm{CD}$ as a nurse in a paediatric unit, and private meetings with people living with the disease. The pre-understanding regarding the studied phenomenon was written down by the author as a way to identify her own knowledge and preconceptions in order to increase her awareness of them. Phenomenology is an approach that takes informants' subjective experiences as its main focus which, from a nursing perspective, is considered of value to study.

\section{Data collection - Interviews}

Studies I and IV were performed in the years 2008 and 2009 respectively. The data comprises 15 and 14 tape-recorded interviews respectively, as well as demographic data about age, time since diagnosis, civil status, domicile and education level. All interviews were conducted by the author. Personal narrative interviews [122] were held before the start of the PE (I) because it was considered important that participants had not been affected by this, and (IV) within two weeks of completion of the PE program; that is, about three months after the first interview. The interviews took place in a suitable room at the hospital in each city involved, or in the woman's home if this was the choice of the informant. The interviews in study I lasted 30-60 minutes 
(median $42 \mathrm{~min}$ ). With the aim of creating a safe interview context, all interviews started with the researcher giving a description of the purpose of the study, how the collected data would be handled and subsequently communicated through publication. Phenomenological interviewing may be very different depending on the approach used [123]. Giorgi (1997. pp.242) claims that "questions are generally broad and open-ended so that the subject has sufficient opportunity to express his or her view point extensively" [124]. In order to focus on the phenomenon under study, i.e. what life is like as a woman living with $C D$, all interviews started with the same question, namely: Will you please tell me what it is like being a woman, living with coeliac disease? Interviews in study IV lasted between 40-70 minutes (median $58 \mathrm{~min}$ ), and the question here, posed to all participants, was: Could you please tell me whether you think the education program you participated in has influenced your daily life, and if so, in what way?

In qualitative interviews, it is important for the researcher to comply with the informant's story by listening, and to avoid directing the interview [122]. Informants were therefore encouraged to talk freely, and probing questions were asked when the interviewer wished to search for a deeper explanation of the phenomenon, such as: "What happened then? Can you say some more about that? Can you give me an example?" One pilot interview with a female colleague with $\mathrm{CD}$ (not included in the analysis) was carried out specifically to test the question (I) and interview skills. A co-author listened to and read the transcribed interview and then scrutinized the interview technique. The interviews were transcribed verbatim by the author and emotions that 
emerged during the interviews, i.e. laughter, tears, snorts and pauses etc. were noted in the transcribed text.

Data analysis

The analytic process followed the general outlines derived by Giorgi [121,125] (Table 3). The aim of the analysis is to, as closely as possible, capture the phenomenon as experienced within the context in which it takes place. Phenomenological analysis seeks to discern the essence of the phenomenon, i.e. it looks for the meanings that constitute the phenomenon by analysing the contexts of the participants' lives [126].

Giorgi's analytic process is sometimes described in four steps [121], and sometimes in five [125]. Regardless of which reference the analysis procedure is based on, the content of the steps, described below, are included in the analysis:

1. Naïve reading, i.e. the interviews were read through, at the same time as listening to the tapes, in order to get a first superficial interpretation. This step provided ideas about the sense of the whole and how to proceed with further analysis.

2. The interviews were then read once again, but this time with the goal of identifying smaller parts, meaning units, within the perspective of the phenomenon of being a woman living with $\mathrm{CD}$. To avoid theoretical explanations, data was kept at as concrete a level as possible. A meaning unit could be part of a sentence or a paragraph.

3. Transformation. In this step, the content of each meaning unit was made clear from the scientific perspective of nursing. Such a description can be conducted on the basis of the question: What does 
this particular meaning unit tell me as a nurse about the experience of living with $\mathrm{CD}$ ? This is a process of reflection and imaginative variation, i.e. an analytic process where the content is varied until the most accurate description is obtained. The transformation of meaning units is helpful in identifying the components of the phenomenon, the so-called constituents.

4. In the last step of the analysis the relationships between the meaning units and the constituents and between the constituents themselves were investigated in order to understand the deeper structure of the phenomenon. This understanding requires consideration of the data, both in parts and as a whole. The general structure, i.e. a new whole, was synthesized into a depiction of the phenomenon of being a woman living with coeliac disease.

The results of the descriptive approach include descriptions of findings rather than theories or hypotheses [121]. 
Table 3. Example of the analysing steps 2-3 regarding study IV. Where a double-slash (//) appears in a quotation, some parts considered non-essential to the reader's understanding of the text have been omitted.

\begin{tabular}{lll}
\hline Expressed meaning & Transformed meaning & Constituents \\
units & units & \\
\hline I am not alone in & The woman feels less & Togetherness creates \\
having these problems. & lonely with her & strength \\
// Although I knew this & problems when she \\
before of course, but I & realizes that there are \\
have never known & many other people with \\
anyone else (with CD) & similar experiences who \\
before except for my & "speak the same \\
sister, and now I know & language" as she does. \\
many others that have & This makes her feel less \\
the same or similar & alone and less \\
problems and we can & vulnerable. \\
talk about it and they & \\
understand exactly what & \\
I mean! Uh, and it & \\
makes you feel less & \\
(short pause), // alone! I & \\
do not feel as & \\
vulnerable// & \\
\hline
\end{tabular}




\section{Studies II-III}

\section{Intervention}

An expert in the field of PBL was linked to the project and influenced the design of the intervention. The groups were conducted by a tutor. After receiving names from the author of the women randomized to the intervention group, the tutor invited participants to the PE, which started a few weeks after the completion of the interviews in study I. Women $(n=54)$ randomized to the intervention group took part in a ten-session educational program, with weekly meetings in groups of 7-9 people. The meetings were held for the purpose of ensuring suitable premises in hospitals (four groups) or universities (three groups). Each meeting lasted about 1.5 hours, but the time varied slightly depending on the content of the meeting in question.

A total of five tutors, all women, were involved in the project, of which four were nurses and one was a behavioural scientist. It was not necessary for the tutors to possess special knowledge regarding gastroenterology or $\mathrm{CD}$, but it was regarded as crucial that they were familiar with the PBL pedagogy. In cases where the tutor had no prior knowledge at all regarding the pedagogy of PBL (one tutor), or if the person's experiences had faded over time (one tutor), the expert in the field who was assigned to the project trained these tutors in their home town. This field expert was also available to the tutors via email and telephone throughout the intervention period to answer pedagogical issues that arose in the groups. The expert was contacted on two occasions and by different tutors. 
In accordance with the PBL philosophy [104] three main features of the education program of this study were emphasized: working in small groups, starting from real life situations, and using a problem-solving process that stimulated self-directed learning. The main purpose of the programme was to support and encourage the participants to find possible facilitating changes in lifestyle, i.e. tools to master their own disease, and thereby increase their subjective well-being and achieve new knowledge within the area.

At the first meeting with the group participants, the tutors introduced PBL, as a pedagogical philosophy and method of learning. Each session considered a predetermined specific topic, presented as a scenario that illustrated the subject of the session in some way. The different scenarios in the course could be selected in the order that participants thought was appropriate. The ideas when developing the scenarios used originated from the results of study I and prior studies $[56,82,127]$. The scenarios took their starting points from everyday problems, which is one of the fundamental ideas of PBL [128] and had the form of a short text, a picture or a section of text from a daily paper or periodical. Areas covered were: anxiety and fears associated with $C D$, obstacles in daily life (Being in control), attitudes to surroundings (Being seen and included), psychological reactions, coping strategies, (Being secure), new knowledge in the field and various questions associated with food and cooking.

The work in the groups with the scenario in question was based on the problem-solving process (Table 4) $[129,130]$. The process of learning in PBL starts with brainstorming about the current scenario, concluding with a 
presentation of the problems of interest. The participants then decide on tasks to investigate together [131]. The group members performed self-studies between the meetings, and tried to answer questions on issues they had previously agreed to investigate. At the next meeting, group members discussed new information they had collected and reflected upon what impact this information would have on their daily lives. New questions of interest then arose after a new brainstorming, and so on [132] .

Table 4. The structured problem-solving process used in the PE as described by Tingström et al. (2005) [130].

Step 1 Clarification of terms and phrases

Step 2 An exact description of the phenomenon that needs to be explained or understood is formulated

Step 3 Brainstorming to formulate various explanations

Step 4 Elaboration of a "theory" regarding the process underlying the phenomena

Step 5 Formulation of issues for self-directed learning

Step 6 Self-studies in order to fill knowledge gaps

Step 7 Integration of new knowledge from the group members and consideration of whether this knowledge is sufficient

According to Boud \& Feletti (1997), the tutor should guide and assist the group through each stage of their discussion and decision-making. The tutor should also prevent and mediate difficulties in the group interaction if they occur. The tutors' role in the groups was to act as facilitators and not as teachers [133]. 
The expert on the issue of PBL served as a supervisor for the instructors in the current study, throughout the intervention period. The participants in the PE received a folder with information about the PBL method and about different areas of the scenarios.

All groups had the opportunity, if requested by the participants, to invite various external resources to the groups, such as nutritionists, chefs, physicians etc. These people did not function as lecturers in the groups but were included in particular meetings and answered questions which had either been compiled in advance or which arose during the meeting. In all groups, at some point, group members discussed where to find reliable information about the disease, and also investigated the literature about CD that had been published in recent years. The groups started at intervals of a few weeks in order to give the supervisor the opportunity to help one group at a time to get started. Group attendance was high (except for one person who took the decision to quit the study). In addition, a total of five people were absent at some point.

Women $(\mathrm{n}=52)$ randomized to the control group received information about which group they belonged to by postal mail. They then received a total of five circulars by postal mail over a ten-week period, containing written information. The information covered evidence-based details of CD corresponding to that offered to adults with established CD seeking medical advice for the disorder in primary care. This information consisted of brochures dealing with origins, symptoms, diagnosis and treatment concerning $\mathrm{CD}$, and information about current research within the area. 


\section{Data collection - self-administered questionnaires}

Studies II \& III were performed during the years 2008-2009. Data was collected at baseline and after 10 weeks in both the intervention group and in the control group. Six months after completing the intervention, data was collected again with regard to intervention group members. After randomization, at baseline, all questionnaires were sent out by post, as was the case for the control group at the 10-week follow-up. The intervention group received the questionnaire from the group tutor at the two follow-ups, but completed them at home. These questionnaires were then sent back in a common envelope for the whole group at the next group meeting. The members themselves put the completed questionnaires in the envelope, which was then sealed. The tutor of the group posted the envelope to the author's office address.

Demographic data was collected by a questionnaire constructed by the authors that was distributed together with the consent form during the information meeting in the cities included. Issues included information concerning age, time since diagnosis, civil status, domicile and level of education.

The two questionnaires used to assess subjective well-being over the past week were self-administered. Both instruments had well-documented reference values for a healthy normal population [85]. For the assessment of general well-being (II), the Psychological General Well-Being (PGWB) index was used. It was developed specifically to measure subjective well-being or distress. [134]. The PGWB protocol consists of 22 items that, apart from 
combining into a global overall score, are combined in six dimensions: anxiety (nervousness, tension, anxiety, relaxedness, stress), depressed mood (depressed, downhearted, sad), positive well-being (general spirits, happy, interested in daily life, cheerful), self-control (firm control, afraid of losing control, emotionally stable), general health (bothered by illness, healthy enough to do things, concerned about health) and vitality (energy, wakes feeling rested, vigorous, tiredness). Each dimension comprises three to five items (see above) using a six-grade Likert scale [135]. The maximum value of 132 indicates optimal well-being and the minimum value of 22 corresponds to a very poor level of well-being [136]. Reference values in a healthy normal population are 100.2-102.6 for females and 103.4-105.6 for men [85].

Gastrointestinal symptoms (III) were evaluated with the Gastrointestinal Symptom Rating Scale (GSRS). The instrument consists of 15 items, each asking how bothered a person is about the presence of commonly reported GI symptoms [135]. Subjects respond using a seven-grade Likert scale defined by verbal denominators that range from no symptoms to the most pronounced symptoms ( $1=$ no discomfort to $7=$ very severe discomfort) [137]. Based on a factor analysis, the 15 items are broken down into five dimensions: Abdominal Pain (abdominal pain, nausea, and hunger pains); Reflux syndrome (heartburn, acid regurgitation); Indigestion syndrome (borborygmus, abdominal distension, eructation, increased flatus); Diarrhoea syndrome (diarrhoea, loose stools, and urgent need for defecation); and Constipation syndrome (constipation, hard stools, feeling of incomplete evacuation), [136]. The gastrointestinal (GI) total index is the mean of these 15 symptoms, and the index value for a clinical syndrome is the mean of all items within an individual scale [137]. Reference 
values in a healthy normal population are 1.52-1.59 for females and 1.46-1.53 for men [85].

\section{Statistical data analyses}

A parametric test was regarded as appropriate for analysis, since the data in studies II and III were normally distributed (scatter plot Gaussian distribution), and summarised in an index.

An ANOVA was used for comparison between the assessments at baseline, ten weeks and six months after completing the intervention in the intervention group. A paired t-test was used to compare within each group, from baseline to ten weeks in both groups, and from baseline to six months in the intervention group. An independent T-test was used to analyse the difference between groups at baseline and also to analyse the difference in improvement between groups from 0-10 weeks.

A comparison of scores between the intervention group and the control group from baseline to ten weeks was performed with a t-test for Equality of Means where equal variances were not assumed. The significance level was set at $\mathrm{p}<0.05$. All statistics were calculated with advice from a statistician. Statistical Package for Social Science, version 17 was used for statistical analysis. 


\section{Study V}

\section{Content analysis}

Content analysis (CA) is primary useful to answer research questions with the aim to explore feelings, thoughts, perceptions, attitudes or motives [138], and is therefore suitable for research in nursing. It aims to analyse data, then categorise and classify it related to a specific context that an individual, a group or a culture attributes to it. The research technique of CA allows for making valid and replicable inferences from a text to the context of its use [139]. Various kinds of CA are described in the literature. In this thesis, CA as described by Krippendorff has been used for analysis. This method is helpful to analyse various types of data, and according to Krippendorff there is no reason to distinguish between quantitative and qualitative CA. He claims that all reading of a text may be considered qualitative, even in cases where certain characteristics of the text are later converted into numbers [139].

\section{Data collection - Interviews}

This study was carried out over the years 2014-2015. Sociodemographic background data regarding; age, time since diagnosis, civil status, domicile and education level was obtained, but also information about subjective wellbeing over the past week by using the two self-administered questionnaires PGWB and GSRS. Furthermore, the data comprised 22 recorded semistructured interviews, of which half were with women and half with men. The author conducted all the interviews and the informants were free to choose a location for their interview. Consequently, 18 interviews were conducted in a 
secluded room at the university in one of the included cities, and four were in participants' own homes.

An interview guide was constructed with open-ended questions [139], based on the results of previous studies in this thesis and a literature review. It provided a framework for all interviews, see Table 5. It was pre-reviewed by experts in the field of $\mathrm{CD}$, who only suggested minor changes regarding wording.

Table 5. Overview of the main questions in the interview guide used in study $\mathrm{V}$

What remaining discomfort do you still have that you believe is caused by your CD?

What do you think the discomfort that you still have, even though you are following a GFD, is caused by?

How do you deal with the problems that you are experiencing to get relief?

When the interviewer searched for a deeper explanation, probing questions were asked such as: 'Why...?' or 'How...?' In order to test the interview guide one pilot interview was conducted. This interview is included in the study, as it did not result in any changes in the interview guide. The interviews lasted from $18 \mathrm{~min}$ up to $59 \mathrm{~min}$, (median $43 \mathrm{~min}$ ). 


\section{Data analysis}

Data in study V was analysed by qualitative CA according to Krippendorff (2013). This method was chosen because it was considered appropriate for analysis of the experiences, management and beliefs of residual discomfort in the interviews. This was an inductive approach, which means that the answers to the research questions were derived from the data. Krippendorff is of the opinion that the contents of the analysis emerge in a process where the researcher analyses the text in relation to the context in which it takes place. Furthermore, he believes that all text written must be of importance to the readers, and not only to the person who performed the analysis. For this reason, $\mathrm{CA}$ is not restricted to anything that is inherent in the text and that is measurable without interpretation by researchers or readers. This means that there will always be a certain interpretation of a text [139].

This study aimed to shed light on women's perspectives by also including men, and then contrasting the groups' experiences in the field. Data collection and analysis were performed in parallel until the point was reached where no further information could be added to the analyses [140]. The author transcribed all 22 interviews verbatim, and read them several times in order to obtain an overview of the whole. Ideas emerging during this reading were noted in the margin. In the next step, the text was broken into smaller textual units relevant to the aim, and then condensed, i.e. reduced but with context retained. Textual units with similar content were identified and grouped together, and then coded into preliminary sub-categories. In the next step, in order to increase the validity of the findings [139], the author and a co-author 
independently coded five of the informants' transcribed interviews and then compared the codes to clarify and discuss any discrepancies. The coding showed high agreement. The researchers continued with this interactive process until a set of commonly agreed codes were created. The remaining transcribed interviews were then coded by the author. Sub-categories with similar meanings were grouped together into categories, while striving to remain open to as much variation in the material as possible. This implied searching for regularities, patterns and contradictions building up subcategories and categories [139]. No data was omitted in the analysis because it did not fit into any category.

Thereafter, for the purpose of further illustrate and describe the pattern of the results to obtain an improved understanding of the material, based on what was considered important by the respondents, also number of statements in the data analysis were counted and presented as part of the results [139]. Finally, a qualitative comparison between women and men were performed.

The PGWB index and the GSRS total score were compared with norm values drawn from the Swedish population with the objective of creating background variable [85]. The Mann-Whitney U-test was used for comparison between women and men, and the significance level was set at $\mathrm{p}<0.05$. The informants scored values below the norm, but there was no statistical discrepancy between women and men. 


\section{Ethical considerations}

All the participants who took part in studies I-V gave their written informed consent and the studies were conducted according to the Declaration of Helsinki [141]. The studies were approved by the Regional Ethical Review Board at Linköping University, Linköping, Sweden (Dnr M218-08), Studies II and III have been registered at www.clinicaltrials.gov: (NCT 010 88152).

At the first meeting (II-III), all intervention groups wrote a contract in which the members agreed that everything that was said during the group meetings would stay in the group and would not be passed on. For ethical reasons, all members of the control group were offered participation in a corresponding PE after 10 weeks.

The recruitment procedures in study $\mathrm{V}$, where potential informants received an information letter from a person they did not have a care-relationship with, may be perceived as a violation of personal integrity. However, the advantages were considered to outweigh the disadvantages, not least as this group is often left without follow-up after diagnosis. All the informants in the study reacted positively to the attention that was given to their problems. They were guaranteed confidentiality (I-V) and were informed in writing (I-V) and verbally $(\mathrm{I}, \mathrm{IV}-\mathrm{V})$ that they could end their participation at any time, without giving a reason. All collected data (questionnaires and transcripts) was anonymized, coded and stored in a locked safe in the author's office. Contact with a social worker at a clinic of internal medicine could be arranged to the informants if necessary. However, this was never needed. 


\section{Establishing rigour in the thesis}

Rigour in research means a striving for excellence. Efforts to achieve rigour imply discipline, scrupulous adherence to detail, and also a great accuracy [142]. The criteria and terminology used in the description of how to achieve rigour in the findings of a study may differ with respect to qualitative and quantitative research [138].

In qualitative research, Lincoln and Guba (1985) have established classic standards. These imply that trustworthiness, meaning the "true value" of data, has been established. Four criteria are recommended by these authors to establish the trustworthiness of qualitative conclusions, namely: Credibility; Dependability; Confirmability and Transferability [143]. Measures taken to meet these standards in the qualitative studies (I, IV-V) included in this thesis were as follows:

In order to establish credibility, which means ensuring that the investigation is carried out in such a way that the results are reliable, the goal was to become aware of my own posture toward data by writing down my preunderstanding of the phenomenon before starting the interviews, as well as purposefully select informants to assure maximum variation. Another measure taken was that the author and a co-author independently read five of the transcribed interviews to reach consensus regarding the approach to further analysis.

Dependability, i.e. showing that the findings are consistent and can be repeated, was ensured by the author performing and transcribing all 
interviews and also by the co-authors giving comments and criticism on the interview technique, as well as questioning each step of the analysis to find possible alternative interpretations. The analysis was discussed until agreement was reached.

Confirmability means the extent to which the findings of a study are shaped by the respondents and not biased by the researcher, due to his/her motivation, or interest. This was ensured by the author writing down her preunderstanding regarding the studied phenomenon to identify her own knowledge and preconceptions to raise her awareness of them, and by providing quotes from the interviews as examples of explicated meanings.

In order to show that the findings have applicability in other contexts, called transferability [144], rich descriptions of the context of informants are provided.

In quantitative research, the terms 'validity' and 'reliability' are used in regard to enhancing rigour. Validity refers to the extent to which an instrument measures what is to be measured, while reliability refers to the consistency of repeated measures of the same attribute when using the same scale or instrument over time [142]. The instruments (PGWB index and GSRS scale) used in the quantitative studies in this thesis (II-III) to assess subjective wellbeing over the previous week, have been extensively used, not least with people suffering chronic intestinal diseases. They were therefore considered appropriate. The PGWB index has good evidence supporting internal 
consistency, validity and test-retest reliability [85,135,145]. In a European patient population with duodenal ulcer, the GSRS received good internal consistency reliability [136], and acceptable construct validity and responsiveness $[135,136,146]$. In order to create homogeneous groups, the participants were randomly assigned to either the intervention group or the control group. 


\section{RESULTS}

The results, presented in this section, are based on a summary of the main findings of the individual studies included in the dissertation. This means that similarities and differences in the results from the different studies have been compared and then compiled into a new whole in order to obtain a broader picture of experiences of living with $\mathrm{CD}$ in remission. The different studies are indicated with Roman numerals.

\section{Daily life experiences of living with CD}

\section{Striving for a normal life}

The overall and essential result regarding experiences of living with CD in remission, was described by participants as a constant quest for a normal life. The desire to live as normally as possible, despite the disease, was prominent in the results from studies I and V. People with CD described different aspects of their efforts to reach this goal, but they also described the various barriers that exist. Three constituents representing conditions necessary to achieve a normalised lifeworld were described in study I as: being secure, being in control and being seen and included. The balance of thoughts in relation to these constituents proved to be crucial for the individual woman's ability to experience a normal life, despite the disease. When one of the constituents was threatened, a normalised lifeworld could not be experienced. The women's 
narratives revealed both positive and negative sides of these constituents, and life with CD meant a constant movement between conflicting feelings.

The striving to live a normal life included that all participants tried, with varying results, to manage their persistent symptoms in every possible way (V). The management resembled thorough detective work. Everyone tried to find the missing puzzle piece, i.e. assess various opportunities that could lead to improved well-being, and thereby a normal life. Also various strategies to prevent problems in the striving for a normal life were expressed.

\section{Conditions and measures facilitating a normal life}

Various conditions facilitated the ability to live with a disease burden and were necessary to achieve a normalised life despite $\mathrm{CD}$, according to the women in study I. These various conditions involved the women's own coping strategies, but also various conditions in the environment. The first condition: feelings of security in different situations in life, revealed that the women's own home was considered to offer security, but as soon as they left it the problems started. Women feeling secure considered themselves able to make deliberate choices that facilitated daily life by choosing the "right" sort of thoughts.

The second condition to achieve a normalised lifeworld was expressed as: being in control by planning. To gain control over situations in life, things were often planned in detail. Situations that were subject to planning included eating out and social encounters. For this reason, restaurants were telephoned and prepared in advance, and when invited to visit someone, women brought something to eat themselves. The third condition necessary to experience a 
normalised life, was expressed as: feelings of being seen and included in various contexts. This was affected by how the women were responded to in relation to their disease. For example when other people showed positive attention in terms of knowledge and caring, such as cooking the same, gluten-free, food for all guests, feelings of being seen and included arose.

Also the management of residual symptoms was deemed significant in order to live life as normally as possible (V). Both women and men reported similar troubles with residual discomfort and similar ways to deal with them. It was considered important to listen to your bodily signals and try to feel what triggered the symptoms. Various options, other than avoiding gluten, were tested, as everyone was already following a GFD. Some people with CD tried to eat a naturally GFD, i.e. a diet based on food that does not contain gluten naturally. To abstain from food during periods when symptoms were perceived as most difficult was described by some as providing symptom relief, while others, however, considered it important to eat regularly when they felt their worst. Also, different vitamins and minerals, medicines intended for entirely different diagnoses, various forms of alternative therapy like reflexology, acupuncture, rose therapy, health food products etc. were tested in order to get symptom relief and thus an opportunity for a more normal life. Distraction measures such as reading books, solving crossword puzzles, various forms of work, walking or lying on an acupressure mat, were considered to relieve physical as well as psychological symptoms. Also relaxation was considered to relieve symptoms, and physical activity was expressed as one of the main weapons against symptoms such as fatigue, anxiety, stiffness and pain. 
People with $\mathrm{CD}$ also mentioned various strategies to prevent problems related to their disease $(\mathrm{V})$ in order to strive to live as normally as possible. One strategy was expressed as withdrawing from situations such as social contact, visiting health care, or walking outside. Reasons to withdraw from such situations included not wanting to show others that they did not feel well, not wanting to be looked upon as cheaters, or to avoid causing trouble for others. The strategy expressed as "overcoming the constraints caused by the disease", facilitated opportunities to live as normally as possible. For that, it was necessary to embrace thoughts of acceptance. Also to compare oneself with other people having poorer health $(\mathrm{I}, \mathrm{V})$, regardless of disease, was considered by some to provide relief, and thereby to feel more normal.

\section{Barriers for a normal life}

At times when one of the three conditions, (being secure, being in control and being seen and included) necessary to achieve a normalised lifeworld (study I) was disturbed, it was hard not to be reminded of the disease.

Informants that expressed themselves as insecure also experienced distrust and a limited ability to make choices in life. It was felt that there was a lack of knowledge about $\mathrm{CD}$ in society $(\mathrm{I}, \mathrm{V})$, and the disease was considered to hinder a normal life for reasons such as rejected employment applications and incomplete education (I). Also, in food-related situations people sometimes experienced insecurity because they were worried about causing problems for others (I, V).

Situations difficult to remain in control over, and thereby offsetting a normal life, were described as the days when they had to be close to a toilet, or when 
worrying about possible consequences of getting old and thus perhaps losing control of what kind of food they were served (I).

Situations where $C D$ women felt un-seen, and thereby excluded by others were when people around them acted with forgetfulness, unwillingness and ignorance. Women with $\mathrm{CD}$ perceived themselves to be ignored and badly treated, almost feeling invisible, in situations when other people told them that it was so hard to invite them home for a meal, as they considered they could not eat anything (I).

Daily life experiences of living with CD in remission may involve residual symptoms (II, III \& V). The impact of residual symptoms negatively affected the chances for people with $\mathrm{CD}$ to live a normal life. People with $\mathrm{CD}(\mathrm{V})$ revealed that the disease was still continuing to have a substantial impact on their lives after several years of treatment, and similar symptom experiences, such as fatigue, diarrhoea, abdominal pain and depressed mood etc. were described by both women and men. People had a failed expectation of symptom relief as, at diagnosis, they had thought their symptoms would disappear with a GFD. They felt a deep disappointment when they experienced that they did not become symptom-free. The majority experienced more than one persistent symptom, and both physical symptoms and symptoms of a mental nature were present. People with CD believed that the underlying causes of their residual symptoms, despite treatment, were of two kinds. Firstly; "bodily convictions" entailed beliefs such as that the gut never healed completely and that the body developed some form of memory over time, similar to mechanisms of phantom pain. The second kind of beliefs, shared by all people, was that residual symptoms occurred because, in practice, it is impossible to live completely 
gluten-free. It was also said that the residual symptoms had, an impact on their personality. Furthermore, despite many troublesome and persistent symptoms, only a few people had sought medical help. The most frequently mentioned symptoms were fatigue and diarrhoea, and the next most mentioned were abdominal pain and depression (V).

\section{The influence of the PE program on women with CD}

\section{Influence on women's psychological well-being}

In study II, at baseline the participants in the control group stated a better total PGWB- index value ( $\mathrm{p}=0.027$ ) compared to the intervention group (Table 6).

An ANOVA of total PGWB-index values showed a significant difference within the intervention group between baseline, ten weeks and six months after the intervention was completed $(\mathrm{p}=0.024)$. 
Table 6. Index outcome for PGWB in the intervention group (PE program): at baseline, after 10 weeks and 6 months after the intervention was completed and in the control group: at baseline and after 10 weeks. A positive mean difference means an improvement of symptoms.

\begin{tabular}{|c|c|c|c|c|c|c|c|c|c|c|c|c|c|}
\hline \multirow{3}{*}{ PGWB } & \multicolumn{8}{|c|}{ Intervention group } & \multicolumn{5}{|c|}{ Control group } \\
\hline & \multicolumn{4}{|c|}{ Mean index and SD } & \multirow[t]{2}{*}{$\begin{array}{c}\text { Mean } \\
\text { diff } \\
(10 w- \\
0 w) \\
n=51\end{array}$} & \multicolumn{2}{|c|}{$\begin{array}{c}\text { Mean index } \\
\text { and SD }\end{array}$} & \multirow[t]{2}{*}{$\begin{array}{c}\text { Mean } \\
\text { diff } \\
(6 \mathrm{~m}- \\
0 w) \\
\mathrm{n}=50\end{array}$} & \multicolumn{4}{|c|}{ Mean index and SD } & \multirow[t]{2}{*}{$\begin{array}{c}\text { Mean } \\
\text { diff } \\
(10 w- \\
0 w) \\
n=52\end{array}$} \\
\hline & $0 w$ & $\mathrm{SD}$ & $10 w$ & SD & & $6 \mathrm{~m}$ & $\mathrm{SD}$ & & $0 w$ & $\mathrm{SD}$ & $10 w$ & $\mathrm{SD}$ & \\
\hline Anxiety & 22.1 & 5.2 & 23.4 & 4.9 & $1.3^{*}$ & 22.9 & 5.4 & 0.7 & 23.8 & 4.2 & 23.6 & 4.3 & -0.2 \\
\hline Depression & 15.0 & 3.1 & 15.9 & 2.6 & $0.8^{*}$ & 15.3 & 3.0 & 0.3 & 15.9 & 2.5 & 15.0 & 2.7 & -0.8 \\
\hline Well-being & 15.6 & 3.7 & 16.5 & 4.2 & $0.9^{*}$ & 16.4 & 4.2 & 1.0 & 17.2 & 3.6 & 15.2 & 4.0 & $-2.0^{* *}$ \\
\hline Self-control & 14.8 & 2.9 & 15.0 & 2.7 & 0.3 & 14.8 & 3.3 & 0.0 & 15.3 & 3.0 & 13.3 & 4.8 & $-2.0^{* *}$ \\
\hline General health & 13.3 & 2.1 & 14.4 & 2.7 & $1.2^{* *}$ & 13.8 & 3.1 & 0.6 & 14.4 & 2.8 & 13.5 & 3.3 & $-0.9^{*}$ \\
\hline Vitality & 14.6 & 4.4 & 16.1 & 4.7 & $1.5^{* *}$ & 16.1 & 4.9 & $1.5^{* *}$ & 16.9 & 4.1 & 13.9 & 6.2 & $-3.0^{* *}$ \\
\hline Total & 95.4 & 18.3 & 101.4 & 19.1 & $6.0^{* *}$ & 99.3 & 21.0 & 4.1 & 103.3 & 17.2 & 94.4 & 22.9 & $-8.9^{* * *}$ \\
\hline
\end{tabular}

Note. $\mathrm{PGWB}=$ Psychological General Well-Being; $\mathrm{SD}=$ standard deviation; diff $=$ difference; $\mathrm{PE}=$ patient education

${ }^{*} \mathrm{p}<.05,{ }^{* *} \mathrm{p}<.01$ vs. baseline

The answers to the questionnaires within each group revealed a significant increase in total PGWB-index value in the intervention group, after the tenweek PBL program $(\mathrm{p}=0.001)$. This was particularly the case for the indexes: Anxiety $(p=0.016)$, Depression $(p=0.023)$, Well-being $(p=0.026)$, General health $(p=0.002)$ and Vitality $(p=0.002)$. It was not the case in the control group, which instead presented a significant worsening of the total PGWB-index value $(\mathrm{p}=0.006)$ particularly for the indexes: Well-being $(\mathrm{p}=0.002)$, Self-control $(\mathrm{p}=0.007)$, General health $(\mathrm{p}=0.03)$ and Vitality $(\mathrm{p}=0.002)$.

Six months after completing PE, improvement in the intervention group, compared with the baseline, remained significant for the index of Vitality $(\mathrm{p}=0.009)$ (Table 6). 
A comparison of scores between the two groups showed a positive development reflecting the participants' subjective general well-being from baseline until after ten weeks in the intervention group. This was found regarding all indexes, compared with the development in the control group. The difference in improvement was significant concerning the indexes: Depression $(\mathrm{p}=0.003)$, Well-being $(\mathrm{p}<0.001)$, Self-control $(\mathrm{p}=0.004)$, General health $(\mathrm{p}<0.001)$, Vitality $(\mathrm{p}<0.001)$ and for the total PGWB -index value $(\mathrm{p}<0.001)($ Table 7$)$.

Table 7. Comparison of mean PGWB improvement from baseline to $\mathbf{1 0}$ weeks between the intervention group (PE program) $(n=51)$ and the control group $(n=52)$. A positive mean difference means an improvement of symptoms.

\begin{tabular}{l|c|c|c|}
\multicolumn{1}{|c|}{ PGWB } & \multicolumn{3}{|c}{$95 \%$ CI of the Difference } \\
& $\begin{array}{l}\text { Mean } \\
\text { diff }\end{array}$ & Lower & Upper \\
\hline Anxiety 0w-10w & 1.5 & 1.35 & 1.65 \\
Depression 0w-10w & $1.7^{* * *}$ & 1.60 & 1.80 \\
Well-being 0w-10w & $2.9^{* * *}$ & 2.76 & 3.03 \\
Self-control 0w-10w & $2.2^{* *}$ & 2.05 & 2.35 \\
General health 0w-10w & $2.0^{* * *}$ & 1.90 & 2.10 \\
Vitality 0w-10w & $4.5^{* * *}$ & 4.31 & 4.63 \\
Total 0w-10w & $14.9^{* * *}$ & 14.20 & 15.60 \\
Note. PGWB = Psychological General Well-Being, CI= confidence interval; diff=difference; PE=patient \\
education \\
${ }^{*} \mathrm{p}<.05,{ }^{* *} \mathrm{p}<.01, * * *$ \\
\end{tabular}

\section{Influence on women's GI symptoms}

In study III, at baseline the participants in the control group stated a better total GSRS- index value $(\mathrm{p}=0.009)$ compared with the intervention group. After 
ten weeks there were no longer any statistically significant differences in GI symptoms between the groups (Table 8 ).

Table 8. Index outcome for GSRS in the intervention group (PE program): at baseline, after 10 weeks and 6 months after the intervention was completed, and in the control group: at baseline and after 10 weeks. A negative mean difference means an improvement of symptoms.

\begin{tabular}{|c|c|c|c|c|c|c|c|c|c|c|c|c|c|}
\hline \multirow{3}{*}{ GSRS } & \multicolumn{8}{|c|}{ Intervention group } & \multicolumn{5}{|c|}{ Control group } \\
\hline & \multicolumn{4}{|c|}{ Mean index and SD } & \multirow[t]{2}{*}{$\begin{array}{c}\text { Mean } \\
\text { diff } \\
(10 w- \\
0 w) \\
n=51\end{array}$} & \multicolumn{2}{|c|}{$\begin{array}{l}\text { Mean index } \\
\text { and SD }\end{array}$} & \multirow[t]{2}{*}{$\begin{array}{c}\text { Mean } \\
\text { diff } \\
(6 \mathrm{~m}- \\
0 \mathrm{w}) \\
\mathrm{n}=50\end{array}$} & \multicolumn{4}{|c|}{ Mean index and SD } & \multirow[t]{2}{*}{$\begin{array}{c}\text { Mean } \\
\text { diff } \\
(10 w- \\
0 w) \\
n=52\end{array}$} \\
\hline & $0 w$ & SD & $10 w$ & SD & & $6 \mathrm{~m}$ & SD & & $0 w$ & SD & $10 w$ & SD & \\
\hline Indigestion & 3.0 & 1.2 & 2.8 & 1.3 & -0.2 & 2.7 & 1.2 & -0.3 & 2.4 & 1.0 & 2.4 & 1.1 & 0.0 \\
\hline Diarrhoea & 2.9 & 1.8 & 3.0 & 1.7 & 0.1 & 2.4 & 1.6 & -0.5 & 2.3 & 1.4 & 2.4 & 1.6 & 0.1 \\
\hline Constipation & 2.5 & 1.5 & 2.1 & 1.1 & $-0.4^{*}$ & 2.2 & 1.3 & -0.3 & 2.2 & 1.4 & 2.3 & 1.3 & 0.1 \\
\hline Abdominal & & & & & & & & & & & & & \\
\hline pain & 2.7 & 1.2 & 2.1 & 0.9 & $-0.6^{* *}$ & 2.2 & 1.0 & $-0.5^{*}$ & 2.0 & 0.9 & 1.9 & 0.9 & -0.1 \\
\hline Reflux & 1.6 & 1.0 & 1.6 & 0.9 & 0.0 & 1.7 & 1.1 & 0.1 & 1.4 & 0.6 & 1.3 & 0.5 & -0.1 \\
\hline Total & 2.5 & 1.0 & 2.3 & 0.9 & $-0.2^{*}$ & 2.2 & 1.0 & $-0.3^{*}$ & 2.1 & 0.7 & 2.1 & 0.8 & 0.0 \\
\hline
\end{tabular}

Note. GSRS = Gastrointestinal Symptom Rating Scale; $\mathrm{SD}=$ standard deviation; diff= difference; $\mathrm{PE}=$ patient education

${ }^{*} \mathrm{p}<.05,{ }^{* *} \mathrm{p}<.01$ vs. baseline

The answers to the questionnaires within each group revealed a significant improvement in total GSRS-index value in the intervention group, after the ten-week PBL program ( $\mathrm{p}=0.013)$, and for the indexes: Constipation $(\mathrm{p}=0.032)$ and Abdominal Pain ( $\mathrm{p}=0.001$ ). Six months after completing PE the total GSRSindex, for the intervention group still showed a statistically significant improvement in comparison to baseline $(\mathrm{p}=0.029)$, with the index: Abdominal Pain showing a statistically significant improvement $(\mathrm{p}=0.01)$. The control group did not report a significant change in GSRS-index value (Table 8). 
A comparison of scores between the two groups showed a significant positive development in the intervention group compared with the control group, regarding the index Abdominal Pain ( $\mathrm{p}=0.007)$, but no significant difference regarding the other indexes or the total GSRS-index (Table 9).

Table 9. Comparison of mean GSRS development from baseline to 10 weeks between the intervention group (PE program) $(n=51)$ and the control group $(n=52)$. A negative mean difference means an improvement of symptoms.

\begin{tabular}{|l|c|c|c|}
\hline \multicolumn{1}{|c|}{ GSRS } & \multicolumn{3}{|c|}{$95 \%$ CI of the Difference } \\
& $\begin{array}{c}\text { Mean } \\
\text { diff }\end{array}$ & Lower & Upper \\
\hline Indigestion 0w-10w & -0.17 & -0.20 & -0.14 \\
Diarrhoea 0w-10w & 0.03 & -0.02 & 0.08 \\
Constipation 0w-10w & -0.42 & -0.46 & -0.38 \\
Abdominal pain 0w-10w & $-0.47^{* *}$ & -0.50 & -0.44 \\
Reflux 0w-10w & 0.08 & 0.05 & 0.11 \\
Total 0w-10w & -0.19 & -0.21 & -0.17
\end{tabular}

Note. GSRS = Gastrointestinal Symptom Rating Scale; $\mathrm{CI}=$ confidence interval; diff=difference; $\mathrm{PE}=$ patient education

${ }^{*} \mathrm{p}<.05,{ }^{* *} \mathrm{p}<.01$

\section{Influence on women's daily lives}

In study IV, the essential structure of women's lived experiences following their participation in the PE program was found to be an interaction with others with the same disease. The interaction made women feel individually strengthened, and provided them with a broader perspective on life with CD. As a result, this strengthened their sense of self in relation to the disease. Knowledge given by other participants and experts could result in both relief and anxiety. 
Three constituents representing conditions necessary to achieve a realigned sense of self were described in study IV as: togetherness creates strength, comparing creates insight, and knowledge enables reappraisal.

Togetherness within a group of people who "were in the same boat" gave strength. In the group the women with $\mathrm{CD}$ could get answers to their questions from people that shared similar experiences. Feelings of togetherness meant that the disease was perceived as easier to endure in that they now did not feel as vulnerable, which meant they felt less disappointment in various situations. Women's narratives revealed a greater confidence in that they no longer felt themselves to be different from others or troublesome.

It was considered important to compare oneself with others having the same disease. Comparisons could lead to reconsideration of one's own way of dealing with the disease. When comparing themselves with others in the group they gained an insight into their own approach to the disease. The women now believed that a person's approach to the disease was largely influenced by one's personality and to a lesser extent by perceived symptoms. Comparisons of physical symptoms with others could lead to relief, but also to opposite types of emotions, for example they could be reminded that they had a disease.

Sharing knowledge with each other meant reappraisal regarding experiences in everyday life. This could lead to feelings of now having more choices in life regarding practical matters, food, activities and so on that they had previously avoided. New knowledge regarding CD delivered by invited experts could increase women's anxiety and also create doubts about how to live. Why consider changes to a lifestyle that was already functioning satisfactorily? 


\section{DISCUSSION}

The results of this thesis show that life with $\mathrm{CD}$ can be complex. From an external perspective, it might be easy to perceive that being able to restore health by simply changing your diet is quite elementary. But this thesis has showed that it is not.

\section{Daily life experiences of living with CD}

The main result, reflecting experiences of living with $\mathrm{CD}$ in remission, was that there is a common desire to live a normal life. People with CD described different aspects of their efforts to achieve this goal, but they also described various barriers that exist.

The desire to achieve some semblance of normality in life has previously been highlighted among chronically ill people with heart conditions and chronic pain [147-149]. In this thesis (I) the goal of living a normal life was said to require three conditions, namely: being secure, being in control, and being seen and included. One can reflect on what the term "normal life" means in a deeper sense. Is it about living like you did before the diagnosis or living like other people in society, or something else? According to Charmaz (1983) life with a chronic disease involves a loss of self. This can give rise to experiences of reduced control over life and the future. Often it is not just the person's selfesteem that is being lost, but also their self-identity [32]. Women (I) who felt secure in most situations said that they themselves, by deliberately choosing the right kind of thoughts, could decide how their life would look, i.e. they 
could have control. Some of the women expressed for example (I) that they could live quite an ordinary life if they just were willing to do some extra planning, such as bringing their own bread when invited to visit someone. Similar problem-focused coping strategies [35] were expressed in study V such as embracing thoughts of acceptance in order to overcoming the constraints caused by the disease. Hence, participants could appreciate what they could actually do in life. It therefore appears that people who are successful in finding coping strategies on their own, and there by handling everyday problems in relation to their chronic illness, can achieve a high level of wellbeing.

Coping strategies used to identify the causes of what makes you feel unwell have previously been described [148]. Such strategies were employed in study $\mathrm{V}$ with the goal of experiencing improved well-being and thus a more normal life. It was considered important to try to understand what in the surrounding/environment made you feel worse and thereby gain control over residual symptoms. Health-related LOC refers, among other things, to the degree to which people believe that they can have control over the development of the disease [37]. The assessment process in study $\mathrm{V}$ resembled thorough detective work, and since following a GFD was already considered extremely important there were other elements, not linked to gluten itself, which were the focus of assessment. Unfortunately, at times the informants experimented with non-evidence-based methods, such as medicines intended for an entirely different diagnosis. In Sweden, people with CD often experience a lack of contact with health care services after diagnosis [17]. It has been found that self-education is a common coping strategy in self-care due to 
loneliness and lack of follow-up care [78]. Can this lack of support explain these peoples' constant struggle to gain control of residual symptoms? If so, healthcare professionals ought to change their practices regarding the followup for people with CD-associated complications [150]. Such a change would probably also assist in the transition to adapt to the disease and to a GFD, since extra support from healthcare has been found to facilitate this process [151]. People with CD having the opportunity to visit a specialist nurse for support regarding self-care would probably feel a sense of being seen and included, but also to feelings of having control over the disease. The nurse's role in this regard is primarily to regulate the delivery and development of self-care abilities i.e. supportive/educative nursing [111].

Also, emotion-focused coping strategies [35], were employed by people with $\mathrm{CD}$ in order to prevent problems related to their disease $(\mathrm{V})$. These concerned withdrawal from situations such as social settings, visiting the healthcare provider, walking outdoors in daytime etc. To those who do not understand the problems of living with $C D$, these may perhaps be regarded as strategies counteracting the potential to live a normal life. Avoiding harmful encounters has probably been among our most effective coping strategies [152]. Although the current threats may not seem so harmful, this strategy was used to avoid exposing oneself to the risk of being an object of suspicion, of being a nuisance, etcetera, i.e. situations that could undermine feelings of normality. A transition process, concerning health and disease, can be described based on how the individual handles the changes related to a condition such as a chronic disease. An incomplete transition can lead to problems and difficulties on several levels, such as health, suffering, loneliness, and withdrawing from 
society [153]. The strategy to withdraw from different situations, employed by the informants in study $\mathrm{V}$, might be an expression of an incomplete transition process. A nurse has a unique role when meeting people undergoing transitions as nursing aims to promote well-being and health [153]. Nurses need to offer education regarding self-care including methods of compensating for limitations in this ability [111], such as promote changes in coping patterns resulting in raised self-esteem, leading to feelings of security in different situations.

Barriers $(V)$ to achieving a normal life were described as situations which disturbed one of the three conditions; being secure, being in control, and being seen and included (I).

One barrier, which led to insecurity and as a consequence to lost control over various situations, was said to be a lack of knowledge about CD in society. People with $\mathrm{CD}$ are exposed daily to mental stress and much ignorance in society, and sometimes there is even an attitude and belief among the general public that people with $\mathrm{CD}$ can actually tolerate a certain amount of gluten. This would lead people with CD into a position in which they were constantly on their guard $(\mathrm{I}, \mathrm{IV} \& \mathrm{~V})$. Furthermore, $\mathrm{CD}$ is a relatively rare disease that is not well understood by the public. The disease can be hidden in some social situations, but becomes obvious in others [80], making people with $\mathrm{CD}$ aware that they are different from others [154]. There is a need for an attitude change in society through increased knowledge concerning CD per se, but also with regard to these peoples' living conditions. Therefore, nurses should inform families, friends and the general public so that people with $\mathrm{CD}$ do not have to 
feel that they pose a problem. One goal of knowledge development in nursing is to increase the understanding of environments that constrain, support or promote healthy transitions [107]. In this thesis (V) both factors considered to facilitate, and barriers to, a normal life were found.

Residual symptoms, of both a somatic and a mental nature, were considered to constitute a barrier for a normal life, despite long-term treatment $(\mathrm{I}, \mathrm{V})$. The symptoms could lead to difficulties for people with $C D$, such as being unable to preserve anonymity in certain situations, and having to be near a toilet on some days (I). Informants believed (V) that one of the underlying causes of these residual symptoms was that it is practically impossible to live completely gluten-free. This appears to be a correct assumption, as other products than food that obviously contains gluten, might be contaminated with gluten during harvesting, processing, and also packaging [155]. Clear and consistent food labelling in combination with an increased public awareness of $\mathrm{CD}$, would probably reduce the risk of accidental ingestion of gluten.

A fundamental assumption of this thesis is that women with treated $C D$ are not doing well despite treatment, and experience more concern than men, as revealed from results of previous studies' $[42,43]$ etc. In study V, both women and men reported similar troubles with residual discomfort and similar ways to manage them. The concept of "hegemonic masculinity" is often used in discussions regarding men's health. In most societies men traditionally are positioned as strong, stoic and self-sufficient with emotional control etc. [156]. A chronic disease, such as $C D$, might involve pain, fatigue and decreased strength and flexibility that undermine the image of strength and 
independence associated with hegemonic masculinity and the factors that previously symbolized a man's position in the gender order [157]. Can assumptions regarding men's physical and mental strength pose a barrier for men in their striving towards a normal life in that they may prevent men from expressing how they are really doing? Displaying concerns of well-being may be perceived as feminine or as a weakness. It might also be that gender stereotyping by healthcare professionals is so deeply rooted that we assume that males with $\mathrm{CD}$ have no discomfort, as previously seen in the context of IBS [47].

\section{The influence of the PE program on women with CD}

The main results concerning the influence of the PE program on women with $\mathrm{CD}$, were that the PE improved psychological well-being (II) and gastrointestinal symptoms (III) in women with CD to some extent. However, togetherness with other people with the same disease (IV), during the intervention, was considered essential and enabled the participants to acquire a broader view of their own life with $\mathrm{CD}$.

In study II, the participants in the PE reported significant improvement in psychological well-being after ten weeks, whereas the controls, given normal handling, reported a worsening. Also, with regard to gastrointestinal symptoms (III), it was found that women participating in PE reported significant improvements. On measuring this outcome again six months later, the effect remained significant. 
Despite the improvements in psychological well-being and gastrointestinal symptoms for the participants in the PE, the mean total index reached the normative values for PGWB, valid for women, only at ten weeks, but not after six months. At no point in time did this happen for GSRS normative values [85]. This indicates that the influence of PE as described here (II-III) does not seem to be sufficient for women with $\mathrm{CD}$ if the goal is to obtain normative values for GSRS, which must be regarded reasonable. A variety of research methods have been used to explore the usefulness of PBL in PE related to chronic disease management [158], which complicates comparisons of outcomes between different studies. However, Ringström et al. (2010) showed a greater reduction in GI symptoms in people with IBS after they participated in a structured PE, compared to people with IBS in a control group receiving written information only [159]. The presence of a chronic illness can be associated with a substantially reduced QoL and happiness, and increased levels of depression [160], and of course, any kind of improvement is then important. Knowledge given by other participants and experts in the PE (IIIII) reduced concerns for some, but increased anxiety for others. This indicates that it must be questioned whether the design that included sessions with experts was the optimal PE method for this group or whether an alternative set-up would have provided better outcomes. Support groups can provide people facing common issues with the chance to meet and share experiences, strengths, knowledge, emotions and fears in a safe environment without censure [161]. Perhaps support groups could even be a possible alternative. These opportunities are interesting areas for future research. 
In the present studies (II-III) the effect had already waned at the follow-up six months after the intervention was completed particularly as regards the women's psychological well-being. This implies that PE cannot be administered as a single dose. Also, the fact that transition processes occur over time and have a sense of flow, in contrast to a change, which tends to be abrupt [107], indicates that PE should be carried out repeatedly. The question is, however, what interval between educational interventions can be considered optimal? People have to remain motivated in order not to return to their old habits. Management for a person with a chronic disease also necessarily varies over time [162], with adjustments based on changes regarding symptoms and fluctuations in the disease process. This poses a challenge when designing a PE for people who have had their diagnosis for different lengths of time.

The impairment in psychological well-being in the control group at the tenweek follow-up may emphasise the need for, and importance of, discussing with others any new knowledge that has been acquired about one's disease, as indicated by the result of study IV. One could also ask if the procedure of receiving printed information brochures sent to one's home may result in greater anxiety than receiving no information at all. In future studies researchers should also consider having a control group that does not receive printed information.

The assumption that there is a need for $C D$ sufferers to meet and discuss disease related issues with others is supported by the unexpected result, namely that the interaction with others with the same diagnosis seemed to 
have such a significant influence on participants striving to cope with their situation and everyday life (IV). The need to talk with others with the same diagnosis about emotions and experiences in the quest for affirmation and support was also found in a PBL-based intervention in the context of cardiac rehabilitation [163]. CD is by nature a social disease and implies health-related stigma. A lifestyle free from gluten often creates confusion in the environment and strains social contacts [80]. Furthermore, the treatment for CD is about self-governing; the patient must take responsibility for their treatment and for ensuring it is handled correctly [164]. Could it be these factors combined that explains women's need for togetherness with others with the same disease? Self-care support involves attempts from healthcare to enable people, especially those with long-term conditions, to become involved in their disease management and to learn to live with their health problems [112]. However, people with CD in Sweden have no natural contact with health services after diagnosis [17] and therefore do not know whether they are living as expected. Interaction made the women feel individually strengthened and allowed them to acquire a broader perspective on life with $\mathrm{CD}$. Several participants said that they previously felt alone, but now belonged to a group (IV). Could it be that the interaction in the groups contributed to the three conditions described as necessary to achieve a normal life (I) namely: being secure, being in control and being seen and included? Future planning of PE for these people should take into account people's need for interaction with others with the same disease for the purpose of acquiring an overview regarding life with $C D$, developing greater confidence, and daring to try new things in life, i.e. having experiences of a normalised life. 
Research suggests that compared to women, men obtain greater health benefits from social integration [165]. Such information, but also the fact that also men $(\mathrm{V})$ with treated $\mathrm{CD}$ might experience many troublesome inconveniences, implies the importance of also including men in future PE interventions. The reason for only including women in the PE program included in this thesis was that women with treated CD, according to some previous studies $[42,43,110]$, tend to experience more discomfort than men. Furthermore it was assumed that a female-only group would provide a safe place for women to discuss issues and concerns specific to them, and also allow for discussions on sensitive topics such as defecation problems in relation to the disease. Yalom \& Leszcz (2005) stated that homogeneous groups have many advantages such as greater cohesion, offering more immediate support to group members, and providing more rapid relief from symptoms [166]. Against this background, it is perhaps wise for future PE, including people with chronic bowel diseases, to divide participants into sexhomogenous groups.

Finally, suffering from a chronic disease entails changes in life with an impact on identity, roles, relationships, abilities and behaviour patterns [153]. Individuals may have varying abilities to meet the increased demands that the disease places on them in carrying out self-care activities such as taking further measures to look after themselves or seeking assistance from others [111]. Despite many and troublesome residual inconveniences only a few people had sought medical help. Instead everyone tried different self-invented management strategies to get relief $(\mathrm{V})$. Orem claims that nurses can perform a 
wide variety of activities to help patients to move towards a position where they can take a more active and decisive role in their care. Caring for people involves helping individuals to handle their chronic disease and thereby master their own self-care demands [22]. The nurse's professional role has changed over time and today includes responsibility for providing support to chronically ill individuals so that they can meet their self-care goals [167]. This can be accomplished with various nursing interventions, such as PE. Nurses therefore have a central role in providing advice, guidance, education and support [168]. PE should provide examples of how to present their concerns to the environment, and how to feel comfortable in social situations.

\section{Methodological issues}

\section{Studies I \& IV}

A phenomenological design was considered to be the most accurate means to describe the essence of women's life experiences [169]. Phenomenology has several limitations, such as one of the phenomenological ideas about "bracketing" [170]. I question whether it is possible to put aside all previous knowledge. When starting a study there is an existing interest and preunderstanding in one particular area so is it possible to be open-minded during interviews? The intention was to use the afore- mentioned mind-set and the pre-understanding during the interviews. The pre-understanding was also checked several times during the analysing process, but still the understanding might have influenced. 
The strength of studies I and IV are that they provide a deeper understanding of experiences of people living with $\mathrm{CD}$ in remission by using a faithful application of the descriptive phenomenological research design according to Giorgi $[120,125]$. Furthermore, the same women were followed in their lifeworld twice, allowing access to their experiences over time. The author performed and transcribed all interviews and discussed each step of the analysis with the co-authors in order to establish dependability in the results [143]. There are no criteria or rules regarding sample size in qualitative research [171], but it can be assumed that study I had an adequate number of informants as no new information was found in the 13th participant's interview. Qualitative research does not aim to generalize the results, but instead these results have given a broader understanding about what it is to live with $\mathrm{CD}$ in society.

The aim was to achieve a purposeful sample (Patton 2004) with regard to participants' duration of disease, residence, age, civil status and education. However, this was difficult to achieve because there was a limited distribution of these factors in the total sample from which the selection was made. This may have affected the credibility negatively, as a sample with a greater variation might have provided more information-rich cases for the studies.

Another limitation concerning study I may be the fact that all the women who were included had been accepted to the PE program. This circumstance may have influenced the results of this study, because the women either were not experiencing their problems so greatly at the time, as they believed that help was near, or they unwittingly magnified their problems to prove that they 
deserved their place on the program. Another consequence of this selection procedure may be that the transferability [143] of results to the whole group of $\mathrm{CD}$ women may have been affected, since it was found that women in the intervention group initially had a lower level of well-being compared with participants in the control group. This could have been prevented if the interviews in study I had been conducted prior to randomization in studies II - III.

\section{Studies II-III}

As far as we know, this is the first time that PE with PBL has been carried out with this patient group. Strength of the studies is that the dropout rate was very low, and the rate of attendance at group sessions was good.

The goal was to recruit a larger number of participants than those participating. However, this is a relatively small patient population, and we included everyone who was interested in participating and who met the criteria for inclusion in the participating counties. The preferable choice would have been to include only those individuals who expressed the lowest levels of well-being in relation to the disease, and in a larger number. No power calculation was performed prior to studies II and III. This negatively affects the generalizability of the results. To permit such a calculation, a level of what was considered to be an acceptable improvement regarding well-being should have been defined before the studies began [172]. A desirable improvement could be that women in the study would achieve the same levels of well-being as men with treated $\mathrm{CD}$. 
Various factors affected the possibility of evaluating the outcome of the intervention (II-III). One is the fact that there was a discrepancy in total mean index value between the groups at baseline, despite randomization [173], where the controls stated a better psychological well-being (II) and fewer GI symptoms (III). It can be assumed that, for this reason, women in the intervention group were more motivated initially compared to the control group, since it seems natural that the greater perceived problems, the greater the motivation to carry out changes in one's life.

Another question is to what extent the procedure for randomization (I-II) can explain the differences between the groups at baseline? Randomization would have been more reliable if women were randomly assigned on the basis of one sample [174]. However, this was not possible as we could not request a person living in one particular town to travel several miles to receive PE. For this reason we had to perform randomization for one city at a time.

Out of the total number of women randomized to the intervention group, 15 people were interviewed (I) a few weeks before the intervention started. Could these interviews have affected the outcome of PE, in the sense that these women began to think about factors associated with their life with $\mathrm{CD}$ that they had not been so aware of before; i.e. that they normally might not have considered to be a major concern in their everyday life?

The circumstance that the participants in the control-group were offered PE after only ten weeks constitutes perhaps the greatest limitation of studies II and III, as this procedure precluded a six-month follow-up with this group. 
This means that it is difficult to determine that it really was the participants in the intervention group that felt the best.

\section{Study V}

A qualitative CA approach was chosen due to the exploratory nature of the study [139]. CA is like a cook-book approach on how to analyse content in all kind of texts, but limitations might be that CA do not give depth in the analysis, like for example hermeneutics, nor does it have a scientific framework. A scientific framework may be of guidance when it comes to level of interpretation and what actually is in focus (phenomena, processes, experiences, conceptions etc.) for a specific research approach. But still CA is useful as it gives an overview and creates valid data on the border to quantitative science [139].

No histological evaluation was performed as this would have necessitated a medical examination which could have been experienced as unpleasant. However, judging from the informants' interviews they were all adhering strictly to a GFD. The result of this study expresses nothing about how common it is for people with CD to experience residual discomfort. Nor can it be proved that reported symptoms were due to the disease as other ongoing illnesses did not constitute a criterion for exclusion. This limits the transferability i.e. the possibility to compare the results from this study to a broader context [143]. However, this was not the purpose of the study. This study describes symptoms that individuals still perceive and which they believe has to do with their CD despite following a prolonged GFD. Another factor that may affect the ability to generalize the results is that all the 
informants experienced persistent symptoms since that was a criteria for inclusion. In the general CD population it is "merely" $30 \%$ of treated people that experience residual symptoms [7]. However, if the data have been carefully collected and analysed, the results are transferable to groups or contexts with similar characteristics [139]. The collected data were rich and gave consistent picture which proposes that the informants were comfortable in their descriptions. Furthermore, the homogeneous experiences among participants indicate that the result can be transferred to both CD women and men.

\section{Concluding remarks}

The reasons that some women and men with $\mathrm{CD}$, despite long-term treatment with a GFD are not doing well seem to be very complex. They may, irrespective of gender, experience residual discomfort of both a somatic and mental nature, which is considered to influence their personality. Experiences of insecurity and of losing control, and the sometimes uncomprehending attitude of society can contribute to difficulties in relation to women's life with the disease, and may adversely affect their common desire to live a normal life. A PE based on PBL (II-III) can, to some extent, improve psychological well-being and gastro-intestinal symptoms in women with CD, but not sufficiently. In coping with CD, it seems essential for women to interact with others with the same disease. Future PE interventions for these people should take this into account. The management of persistent discomfort in women and men resembles thorough detective work. They believe that it is impossible to live completely gluten-free, which could be one of the possible explanations 
for residual discomfort despite GFD. It is unclear to what extent distress due to role strain and other factors, which have not yet been researched, may contribute to many women with $\mathrm{CD}$ experiencing difficulties in their daily life management of the disease. Another question concerns why experiences from the men who are not doing well in their CD are seldom reported. Future research in this area should focus on finding the answers to these issues in order to develop more effective educational approaches for people with CD. Clinical implications

Nurses should facilitate healthy transitions [107] for people with CD, in order to enhance a sense of living a normal life despite the disease. This implies helping people with $\mathrm{CD}$ to overcome the barriers to reaching this common desire. For this, nurses should support individuals in handling their chronic disease and hereby mastering their own self-care demands [112]. It is important to identify individuals with treated CD that are not doing well, by introducing regular check-ups by a specialist nurse. It seems important that support is initiated from the time of diagnosis to prevent any negative consequences that can arise and it should also be communicated that the patient may experience continued discomfort despite treatment $(\mathrm{V})$. The support should also offer guidance regarding self-care strategies and focus on empowering people in order to provide raised self-esteem. This can be accomplished with various nursing interventions, such as PE.

The possibility for a woman with $\mathrm{CD}$ to experience a normalised lifeworld is affected by a number of conflicting feelings (I), and the results of this thesis provide knowledge, for healthcare and others, regarding the necessary 
conditions. To help the women in their efforts to gain a normalised life, feelings of security and being in control, seems to be an important goal for health care who meet women with CD. A PE with PBL can be helpful for these women in order to identify strategies that facilitate everyday life, and future interventions should perhaps primarily approach the group of women, but also men, who are experiencing difficulties in finding coping strategies. Another important matter to be considered when planning a PE is that women with $\mathrm{CD}$ need to interact with others with the same diagnosis to become individually strengthened and to achieve a broader perspective on life with the disease. However, future PE interventions should take into account that knowledge given by other participants, but also by experts, can result in both relief and anxiety.

Finally, there is a need for an attitude change in society through providing increased knowledge concerning CD per se, but also concerning how these people have to manage their lives to cope with the disease.

\section{Conclusions}

The following conclusions can be drawn from the five studies in this thesis:

- Individuals with treated coeliac disease, irrespective of gender, may experience residual discomfort of both a physical and psychological nature, causing major negative impacts on their lives in different ways.

- In coping with $C D$, it seems that women need interaction with others, with the same disease in order to experience togetherness within a group, get the opportunity to compare themselves with others and to exchange knowledge. This interaction appears to result in people acquiring an overview of life with the disease, developing a greater confidence, and daring to try new things in life. 
- A person with $\mathrm{CD}$ wants to live a normal life. To achieve a normalised lifeworld three preconditions were expressed, namely: feelings of security; a sense of having control of the situation; and feelings of being seen by other people. Both facilitating factors and barriers to living a normal life despite the disease was found.

- A PE program based on an active method for women with coeliac disease can improve the psychological well-being of participants to some extent. However, the results indicate that PE cannot be administered as a single dose, but should be replenished regularly, since its effects tend to wear off over time.

- The effect of the same PE on GI-symptoms was not sufficient in comparison to the outcome in the control group since the comparison of changes regarding development of scores, from baseline to 10 weeks, in the two groups where not significant. 


\title{
SVENSK SAMMANFATTNING SWEDISH SUMMARY
}

\author{
Att leva med celiaki i remission. \\ Dagliga livserfarenheter, symptom och välbefinnande
}

\section{Bakgrund}

Tidigare studier visar att kvinnor med kronisk sjukdom upplever mer symtom än män, medan andra studier hävdar att dylika skillnader inte kan påvisas. Celiaki är en kronisk autoimmun sjukdom som drabbar personer med en genetisk betingning för sjukdomen. Tidigare studier har upprepade gånger påvisat könsskillnader gällande upplevda symtom och sjukdomsbörda. Diagnosen celiaki ställs då en person uppvisar onormal struktur på slemhinnan i tunntarmen som ett resultat av glutenintag, samt en påföljande histologisk och klinisk tillbakagång efter glutenfri diet. Sjukdomen kännetecknas av malabsorption, men det förekommer både många atypiska symtom liksom symtomlöshet. Förekomsten av celiaki i den västerländska befolkningen beräknas ligga omkring 1 \% och är något vanligare hos kvinnor än hos män. Behandlingen vid celiaki innebär en livslång glutenfri diet, vilken antas resultera i en signifikant symtomlindring inom en kort tidsperiod. Det är dock vanligt att personer med behandlad celiaki upplever kvarstående obehag av olika slag samt även, och då i synnerhet kvinnor, lägre välbefinnande jämfört med friska kvinnor i befolkningen men även jämfört med män med behandlad celiaki.

Omvårdnadsområdet innebär ett fokus på att hjälpa människor som har icke tillgodosedda behov i förhållande till sin hälsa eller sjukdom att så långt som möjligt stärka personens självständighet och förmåga till egenvård. En transition innebär en förändring, t.ex. beträffande en persons hälsostatus, och en hälso- och sjukdomsrelaterad transition finns därför närvarande av och till i varje människas liv. Upplevelsen av en transition färgas av många olika aspekter såsom personens kön, ålder, hälsotillstånd etc. En fulländad transition innebär att personen når ett nytt stadium eller en högre nivå av 
varandet. Sjuksköterskor möter i sin yrkesroll människor som genomgår, står inför eller har genomgått transitioner.

Patientutbildning är centralt inom omvårdnad och är en av de åtgärder som kan hjälpa patienter med kronisk sjukdom att uppleva högre livskvalitet. Patientutbildning är inte bara ett sätt att inhämta kunskaper utan måste även bidra till att förenkla och förbättra livet för personerna, så att de kan se de eventuella vinsterna av genomförda livsstilsförändringar.

Det finns i dag många olika pedagogiska modeller användbara i patientutbildningssammanhang. En av dessa är Problem-Baserat Lärande (PBL). Denna metod strävar mot självständighet, funktionell kunskap, kritiskt tänkande och ett livslångt lärande. Signifikanta förbättringar efter patientutbildning med PBL har rapporterats för kroniska sjukdomar som diabetes, astma, artrit och hjärtsjukdom. Trots dessa positiva resultat har PBL inte tidigare använts i patientutbildning vid celiaki.

\section{Syfte och delsyften}

Det övergripande syftet med avhandlingen var att studera personers erfarenheter av att leva med celiaki, samt att bedöma hur en patientutbildning påverkar deras upplevda hälsa och dagliga liv.

Syftet med studie I var att beskriva upplevelsen av att som kvinna i Sverige leva med celiaki. Syftet med studie II \& III var att utvärdera effekten av ett patientutbildningsprogram baserat på PBL, för kvinnor med celiaki i remission avseende psykiskt välbefinnande (II) och tarmsymtom (III). Syftet med studie IV var att undersöka kvinnornas upplevelser från det patientutbildningsprogram som de genomgått för att få ett djupare perspektiv gällande dess inflytande på deras dagliga liv. I studie $\mathrm{V}$ var syftet att kvalitativt jämföra erfarenheter och övertygelser av kvarstående besvär hos kvinnor och män med behandlad celiaki, liksom deras egen hantering av dessa besvär.

\section{Deltagare och tillvägagångssätt}

De första fyra studierna (I-IV), baseras på samma deltagare vilka identifierades via patientjournaler hos dietister på de fem ingående sjukhusen samt via annonser i Celiakiföreningens medlemstidningar. Totalt 106 kvinnor, 20 år eller äldre, med bekräftad celiaki som behandlats med GFD i minst fem år randomiserades (II \& III) med utgångspunkt från bostadsort till antingen 
interventionsgruppen den s.k. "Celiakiskolan" ( $\mathrm{n}=54)$ eller till kontrollgruppen som fick sedvanlig vård $(n=52)$.

Studie I och IV genomfördes i form av kvalitativa intervjustudier med fenomenologisk ansats. Individuella bandinspelade intervjuer utfördes med ändamålsenligt utvalda kvinnor tillhörande interventionsgruppen. I studie I utgjordes deltagarna av 15 kvinnor som intervjuades före starten av Celiakiskolan. För att fokusera på det studerade fenomenet började samtliga intervjuer med frågan: Kan du berätta för mig hur det är att som kvinna leva med celiaki? Deltagarna i studie IV var samma kvinnor som i studie I men nu 14 stycken. Intervjuerna utfördes inom två veckor efter avslutad patientutbildning. Frågan som ställdes till samtliga kvinnor i intervjun var: Kan du berätta för mig om du anser att den patientutbildning du deltagit i har påverkat ditt dagliga liv, och i så fall på vilket sätt? Intervjuerna (I \& IV) analyserades i enlighet analyssteg utarbetade av Giorgi.

Studie II och III är baserade på samma intervention, en patientutbildning baserad på PBL-pedagogik där deltagarna träffades en gång i veckan vid 10 tillfällen. Totalt sju utbildningsgrupper à 7-9 deltagare startade. Det huvudsakliga målet för programmet var att stödja och uppmuntra deltagarna att finna möjliga livsstilsförändringar och därmed redskap att handskas med svårigheter förknippade med sjukdomen. Kontrollgruppen fick information beträffande celiaki hemskickad regelbundet och vid totalt fem tillfällen. Efter tio veckor erbjöds även kontrollgruppens medlemmar att delta i samma patientutbildningsprogram som interventionsgruppen. Celiakiskolan utvärderades före dess start, efter tio veckor beträffande båda grupperna, samt sex månader efter avslutad celiakiskola för deltagarna i interventionsgruppen. Enkäten "Psychological General Well-Being" (PGWB) användes för utvärdering av subjektivt välbefinnande. Tarmsymtomen utvärderades med enkäten "Gastrointestinal Symptom Rating Scale" (GSRS).

Studie V belyser kvinnors perspektiv genom att inkludera även män, och kontrastera gruppernas erfarenheter inom området. Deltagarna (totalt 22 personer varav hälften kvinnor och hälften män), valdes ut ändamålsenligt från regionala vårddatabaser i sydöstra Sverige. Data består av individuella intervjuer med utgångspunkt från en intervjuguide. Huvudfrågorna berörde vilka kvarstående obehag personerna upplevde som man ansåg berodde på celiakin, orsaker till dessa kvarstående obehag samt hur man hanterade dessa 
för att få lindring. Intervjuerna analyserades med innehållsanalys enligt Krippendorff. Datainsamling och analys av insamlat material pågick parallellt tills ingen ny information framkom i intervjuerna.

\section{Resultat}

Avhandlingens resultat (I-V) visar att sjukdomen hade en fortsatt betydande inverkan på deltagarnas liv även efter flera års behandling, och många kvarstående symtom, både fysiska och psykiska, upplevdes (II, III, V).

Det övergripande resultatet, som återspeglar upplevelser av att leva med celiaki i remission, beskrevs av deltagarna som en konstant strävan efter ett normalt liv (I, V). Tre förutsättningar för att uppnå detta uttrycktes som (I): Känslor av trygghet; Känslor av att ha kontroll över situationen samt; Känslor av att bli sedd av andra människor. Hanteringen av sjukdomen inbegrep såväl omständigheter och åtgärder som ansågs underlätta möjligheterna att leva ett normalt liv, men även hindrade dessa möjligheter $(\mathrm{I}, \mathrm{V})$. Sökandet efter den saknade pusselbiten som skulle leda till lindring av kvarstående obehag liknade ett detektivarbete (V), och olika strategier användes för att förebygga problem. Föreställningar om de bakomliggande orsakerna till kvarstående symtom, trots behandling, var att de beror på kroppsliga orsaker, samt att det ansågs omöjligt att i praktiken leva helt glutenfritt.

Utvärderingen av patientutbildningsprogrammet baserat på PBL inom respektive grupp, visar att deltagarna i utbildningen rapporterade en signifikant förbättring beträffande subjektivt välbefinnande (II) ( $\mathrm{p}=0.001)$, och tarmsymtom (III) $(\mathrm{p}=0.013)$ efter tio veckors intervention, medan kontrollgruppen inte förbättrades signifikant. Jämförelse av resultatet mellan grupperna under samma tidsperiod visar en signifikant förbättring beträffande interventionsdeltagarnas subjektiva välbefinnande jämfört med kontrollgruppens deltagare $(p<0.001)$, men däremot ingen signifikant skillnad mellan grupperna avseende upplevda tarmsymtom.

Vid den första utvärderingen, dvs. före patientutbildningens start, rapporterade kontrollgruppens deltagare av okänd anledning och trots 
randomisering, signifikant bättre subjektivt välbefinnande och signifikant mindre tarmsymtom jämfört med patientutbildningens deltagare. Sex månader efter avslutad patientutbildning hade dess positiva effekter avtagit. Interaktioner med andra personer med samma sjukdom under utbildningsprogrammet ledde till att deltagarna kände sig stärkta (IV). Samspelet gjorde det möjligt för deltagarna att få en fördjupad bild av livet med celiaki. Kunskap från andra deltagare och experter kunde resultera i både lättnad och oro.

Avhandlingens slutsatser är att personer med behandlad celiaki strävar efter att kunna leva ett så normalt liv som möjligt trots sjukdom. Möjligheten att nå detta mål kan påverkas av omständigheter som exempelvis kvarstående symtom och att deras problem inte tas på allvar i samhället. De kämpar dagligen på olika sätt för att hantera celiakisjukdomen trots dålig hälsa. En patientutbildning med PBL kan hjälpa dem att uppleva en högre grad av välbefinnande, men interventionsmetoden måste förfinas för att ge en mer uttalad långsiktig effekt. Vid utformningen av ett patientutbildningsprogram tycks det vara viktigt att ta hänsyn till personernas behov av att träffa andra med samma sjukdom, och att fråga dem om deras kunskapsbehov snarare än att som sjukvårdspersonal utgå från att man vet vad de behöver. Det verkar även viktigt att identifiera personer med behandlad $\mathrm{CD}$ som inte mår bra genom att införa regelbundna kontroller av specialistsjuksköterska. Sjuksköterskor kan främja en lyckad transitionsprocess genom att erbjuda utbildning om egenvård inklusive metoder för att kompensera för begränsning i livet. Detta kan genomföras konkret genom att främja förändringar av coping-strategier. En annan åtgärd som sannolikt skulle gynna dessa personer är att erbjuda patientutbildning i samband med diagnos. Detta skulle förmodligen vara kontraproduktivt mot de negativa aspekter denna sjukdom kan medföra i det dagliga livet för de drabbade. Information till personer som just har fătt diagnosen ska förmedla att de fortfarande kan uppleva fortsatt obehag trots behandling. Slutligen finns det ett behov av attitydförändring i samhället genom ökad kunskap om CD i sig, men även när det gäller dessa personers levnadsvillkor. 


\section{ACKNOWLEDGEMENTS}

I would like to express my gratitude to all those who, in various ways, helped and encouraged me during the course of this work. I would like to express special thanks to:

All the women and men with coeliac disease who participated. You took your time to answer questions and told me your life stories.

Maria Friedrichsen, my main supervisor, for your never-ending patience, your constant presence and support, and for always listening to my opinion and believing in me. I have really enjoyed working with you and getting to know you over these years. Thanks for all you have taught me.

Claes Hallert, my first main supervisor, and co-supervisor during the first part of this journey, for your tireless enthusiasm.

Anna Milberg, my co-supervisor, for your tremendous wisdom and accuracy, for all the questions you set that really prompted me to stop and think once more.

Professor Katarina Hjelm, my co-supervisor during the last part of this journey. You have generously shared your knowledge and provided important input to my work. I also want to thank you for giving me the chance to complete my thesis.

Anne Göransson, co-author, for all the good advice during the implementation of PBL in the PE program.

All doctoral students, colleagues and friends at the Department of Social- and Welfare Studies, for your support, stimulating discussions and friendship.

Most of all, my beloved husband Bengt and children Klara, Hannes and Erik, who always believe in everything I take on and who support me, no matter what consequences this entails for them. Special thanks go to you Hannes, for your immense patience in reading and commenting on the different parts of this thesis in order to support me. 


\section{References}

1. Lionetti E, Gatti S, Pulvirenti A, Catassi C. Celiac disease from a global perspective. Best Pract Res Clin Gastroenterol. 2015;29: 365-379.

2. Dubé C, Rostom A, Sy R, Cranney A, Saloojee N, Garritty C, et al. The prevalence of celiac disease in average-risk and at-risk Western European populations: A systematic review. Gastroenterology. 2005;128: 57-67.

3. Garcia-Manzanares A, Lucendo A. Nutritional and dietary aspects of celiac disease. Nutr Clin Pract. 2011;26: 163-173.

4. Dewar D, Donnelly S, McLaughlin S, Johnson M, Ellis H, Ciclitira P. Celiac disease: Management of persistent symptoms in patients on a gluten-free diet. World J Gastroenterol. 2012;18: 1348-1356.

5. Kaukinen K. Altered duodenal microbiota composition in celiac disease patients suffering from persistent symptoms on a long-term gluten-free diet. Am J Gastroenterol. 2014;109: 1933-1941.

6. Paarlahti P, Kurppa K, Ukkola A, Collin P, Huhtala H, Mäki M, et al. Predictors of persistent symptoms and reduced quality of life in treated coeliac disease patients: A large cross-sectional study. BMC Gastroenterol. 2013;13: 18 .

7. Wong R, Steele R, Reeves G, Wilson R, Pink A, Adelstein S. Antibody and genetic testing in coeliac disease. Pathology. 2003;35: 285-304.

8. Barratt S, Leeds J, Sanders D. Quality of life in coeliac disease is determined by perceived degree of difficulty adhering to a gluten-free diet, not the level of dietary adherence ultimately achieved. J Gastrointestin Liver Dis. 2011;20: 241245.

9. Cranney A, Zarkadas M, Graham I, Butzner J, Rashid M, Warren R, et al. The Canadian Celiac Health Survey. Dig Dis Sci. 2007;52: 1087-1095.

10. Ford S, Howard R, Oyebode J. Psychosocial aspects of coeliac disease: A cross-sectional survey of a UK population. Br J Health Psychol. 2012;17: 743757. 
11. Hauser W, Gold J, Stein J, Caspary WF, Stallmach A. Health-related quality of life in adult coeliac disease in Germany: results of a national survey. Eur J Gastroenterol Hepatol. 2006;18: 747-754.

12. Hallert C, Granno C, Hulten S, Midhagen G, Strom M, Svensson H, et al. Living with coeliac disease: controlled study of the burden of illness. Scand J Gastroenterol. 2002;37: 39-42.

13. Glanz, K., Rimer, B., Lewis,F. Health behavior and health education : theory, research, and practice. San Francisco: Jossey-Bass; 2002.

14. Lai D, Ka T, Chappell N, Lai D, Chau S. Relationships between culture and health status: A multi-site study of the older Chinese in Canada. Can J Aging. 2007;26: 171-183.

15. Hjelm K, Bard K, Apelqvist J. Gestational diabetes: prospective interviewstudy of the developing beliefs about health, illness and health care in migrant women. J Clin Nurs. 2012;21: 3244-3256.

16. Hallert C, Sandlund O, Broqvist M. Perceptions of health-related quality of life of men and women living with coeliac disease. Scand J Caring Sci. 2003;17: 301-307.

17. Roos S, Hellström I, Hallert C, Wilhelmsson S. Everyday life for women with celiac disease. Gastroenterol Nurs. 2013;36: 266-273.

18. Enworom C, Tabi M. Evaluation of Kidney Disease Education on Clinical Outcomes and Knowledge of Self-Management Behaviors of Patients with Chronic Kidney Disease. Nephrol Nurs J. 2015;42: 363-373.

19. Battersby M, Harris M, Smith D, Reed R, Woodman R. Patient Education: A pragmatic randomized controlled trial of the Flinders Program of chronic condition management in community health care services. Patient Educ Couns. 2015;Article in press.

20. Gremeaux V, Benaïm C, Poiraudeau S, Hérisson C, Dupeyron A, Coudeyre E. Evaluation of the benefits of low back pain patients' education workshops during spa therapy. Joint Bone Spine. 2013;80: 82-87.

21. Williams B, Pace AE. Problem based learning in chronic disease management: a review of the research. Patient Educ Couns. 2009;77: 14-19. 
22. Meleis A. Theoretical nursing : development and progress. 5th ed. Philadelphia: Wolters Kluwer Health/Lippincott Williams \& Wilkins; 2011.

23. Booker S, Morris M, Johnson A. Empowered to change: evidence from a qualitative exploration of a user-informed psycho-educational programme for people with type 1 diabetes. Chronic Illn. 2008;4: 41-53.

24. Koutsopoulou S, Papathanassoglou E, Katapodi M, Patiraki E. A critical review of the evidence for nurses as information providers to cancer patients. J Clin Nurs. 2010;19: 749-765.

25. WHO. Draft action plan for the prevention and control of noncommunicable diseases 2013-2020. Report by the Secretariat. Geneve: World Health Organization (WHO). . 2013. Available: http://www.vardanalys.se/Global/Rapporter\%20pdf-filer/2014/2014-2VIP\%20i\%20v\%C3\%A5rden.pdf.

26. Gregory S. Living with chronic illness in the family setting. Sociol Health Illn. 2005;27: 372-392.

27. Lawn S, Schoo A. Supporting Self-management of Chronic Health Conditions: Common Approaches. Patient Educ Couns. 2010;80: 205-211.

28. WHO. Health Topics-Chronic Diseases. Geneve: World Health Organization (WHO). . 2014. Available: http://www.who.int/topics/noncommunicable.

29. European commission. $<$ br $/>$ Major and Chronic Diseases and European commission. . 2014. Available: http://ec.europa.eu/health/major chronic diseases/policy/index.

30. WHO. Global status report on noncommunicable diseases, World Health Organization (WHO). . 2012. Available:

http://alliancechronicdiseases.org/assets/docsforsite/pdfs/WHO\%20report $\% 20$ on $\% 20 \mathrm{NCDs} \% 20 \mathrm{in} \% 20 \mathrm{SE} \% 20$ Europe.pdf.

31. Lubkin I, Larsen P. Chronic illness : impact and interventions. 8th ed: Burlington, Mass. : Jones \& Bartlett Learning,; 2013.

32. Charmaz K. Loss of self: a fundamental form of suffering in the chronically ill. Sociol Health Illn. 1983;5: 168-195. 
33. Devins G. Review article: Using the Illness Intrusiveness Ratings Scale to understand health-related quality of life in chronic disease. J Psychosom Res. 2010;68: 591-602.

34. Hundt N, Bensadon B, Stanley M, Petersen N, Kunik M, Kauth M, et al. Coping mediates the relationship between disease severity and illness intrusiveness among chronically ill patients. J Health Psychol. 2015;20: 11861195.

35. Lazarus R, Folkman S. Stress, appraisal, and coping: New York : Springer; 1984.

36. Gibson K, Rueda S, Rourke S, Bekele T, Gardner, Fenta H, et al. Mastery and coping moderate the negative effect of acute and chronic stressors on mental health-related quality of life in HIV. AIDS Patient Care STDS. 2011;25: 371-381.

37. Berglund E, Lytsy P, Westerling R. The influence of locus of control on selfrated health in context of chronic disease: a structural equation modeling approach in a cross sectional study. BMC Public Health. 2014;14: 700-717.

38. Rotter J. Generalized expectancies for internal versus external control of reinforcement. Psychol Monogr. 1966;80: 1-28.

39. Arraras J, Wright S, Jusue G, Tejedor M, Calvo J. Coping style, locus of control, psychological distress and pain-related behaviours in cancer and other diseases. Psychol Health Med. 2002;7: 181-187.

40. Fera T, Cascio B, Angelini G, Martini S, Guidetti C. Affective disorders and quality of life in adult coeliac disease patients on a gluten-free diet. Eur J Gastroenterol Hepatol. 2003;15: 1287-1292.

41. Roos S, Kärner A, Hallert C. Gastrointestinal symptoms and well-being of adults living on a gluten-free diet: a case for nursing in celiac disease. Gastroenterol Nurs. 2009;32: 196-201.

42. Paavola A, Kurppa K, Ukkola A, Collin P, Lähdeaho M, Huhtala H, et al. Gastrointestinal symptoms and quality of life in screen-detected celiac disease. Dig Liver Dis. 2012;44: 814-818. 
43. Casellas F, Rodrigo L, Vivancos J, Riestra S, Pantiga C, Baudet J, et al. Factors that impact health-related quality of life in adults with celiac disease: a multicenter study. World J Gastroenterol. 2008;14: 46-52.

44. Roos S, Kärner A, Hallert C. Psychological well-being of adult coeliac patients treated for 10 years. Dig Liver Dis. 2006;38: 177-180.

45. Lips HM. Sex \& gender : an introduction. Boston: McGraw-Hill/Higher Education; 2008.

46. WHO. Gender, equity and human rights. . 2015. Available: http://www.who.int/mediacentre/factsheets/fs403/en/.

47. Björkman I, Dellenborg L, Ringström G, Simrén M, Jakobsson Ung E. The gendered impact of Irritable Bowel Syndrome: a qualitative study of patients' experiences. J Adv Nurs. 2014;70: 1334-1343.

48. Ordovas JM. Gender, a significant factor in the cross talk between genes, environment, and health. . 2007;4: S111-S122.

49. Rieker PP, Bird CE. Rethinking gender differences in health: why we need to integrate social and biological perspectives. J Gerontol B Psychol Sci Soc Sci. 2005;60 Spec No 2: 40-47.

50. Wolff J, Gemmell N. Mitochondria, maternal inheritance, and asymmetric fitness: Why males die younger. Bioessays. 2013;35: 93-99.

51. England P. The Gender Revolution: Uneven and Stalled. Gend Soc. 2011;25: 113-123.

52. Smirthwaite G, Sveriges kommuner och landsting. (O)jämställdhet i hälsa och vård: en genusmedicinsk kunskapsöversikt. Stockholm: Sveriges kommuner och landsting; 2007.

53. Clarke L, Bennett E. 'You learn to live with all the things that are wrong with you': gender and the experience of multiple chronic conditions in later life. Ageing Soc. 2013;33: 342-360.

54. Prentice D, Carranza E. What Women and Men Should Be, Shouldn't Be, Are Allowed to Be, and Don't Have to Be: The Contents of Prescriptive Gender Stereotypes. Psychol Women Q. 2002;26: 269-281. 
55. Davis R, Magilvy J. Quiet pride: the experience of chronic illness by rural older adults. J Nurs Scholarsh. 2000;32: 385-390.

56. Sverker A, Ostlund G, Hallert C, Hensing G. 'I lose all these hours...'-exploring gender and consequences of dilemmas experienced in everyday life with coeliac disease. Scand J Caring Sci. 2009;23: 342-352.

57. Hamosh A. Celiac Disease; OMIM Nr: 212750. . 2011.

58. Kelly C, Bai J, Liu E, Leffler D. Celiac Disease: Clinical Spectrum and Management: Advances in Diagnosis and Management of Celiac Disease. Gastroenterology. 2015;148: 1175-1186.

59. Green P, Lebwohl B, Greywoode R. Reviews and feature article: Celiac disease. J Allergy Clin Immunol. 2015;135: 1099-1106.

60. Mäki M, Mustalahti K, Kokkonen J, Kulmala P, Haapalahti M, Karttunen T, et al. Prevalence of celiac disease among children in Finland. N Engl J Med. 2003;348: 2517-2524.

61. Tanpowpong P, Camargo C. Early-life vitamin D deficiency and childhood-onset coeliac disease. Public Health Nutr. 2014;17: 823-826.

62. Lebwohl B, Green P, Murray J, Ludvigsson J. Season of birth in a nationwide cohort of coeliac disease patients. Arch Dis Child. 2013;98: 48-51.

63. Riddle M, Murray J, Cash B, Pimentel M, Porter C. Pathogen-specific risk of celiac disease following bacterial causes of foodborne illness: a retrospective cohort study. Dig Dis Sci. 2013;58: 3242-3245.

64. Hrdlickova B, Westra H, Franke L, Wijmenga C. Celiac disease: Moving from genetic associations to causal variants. Clin Genet. 2011;80: 203-313.

65. Green P, Cellier C. Medical progress: celiac disease. N Engl J Med. 2007;357: 1731-1743.

66. Ludvigsson J, Rubio-Tapia A, van Dyke C, Melton L, Zinsmeister A, Lahr $B$, et al. Increasing incidence of celiac disease in a North American population. Am J Gastroenterol. 2013;108: 818-824.

67. Farrell R, Kelly C. Celiac sprue. N Engl J Med. 2002;346: 180-188. 
68. Sharma M, Singh P, Agnihotri A, Das P, Mishra A, Verma AK, et al. Celiac disease: A disease with varied manifestations in adults and adolescents. J Dig Dis. 2013;14: 518-525.

69. Lindfors K, Koskinen O, Kaukinen K. An update on the diagnostics of celiac disease. Int Rev Immunol. 2011;30: 185-196.

70. Ukkola A, Mäki M, Kurppa K, Collin P, Huhtala H, Kekkonen L, et al. Diet Improves Perception of Health and Well-being in Symptomatic, but Not Asymptomatic, Patients With Celiac Disease. Gastroenterol Hepatol. 2011;9: 118-123.

71. Lanzini A, Lanzarotto F, Villanacci V, Mora A, Bertolazzi S, Turini D, et al. Complete recovery of intestinal mucosa occurs very rarely in adult coeliac patients despite adherence to gluten-free diet. Aliment Pharmacol Ther. 2009;29: 1299-1308.

72. Hallert,C.Stenhammar,L.Grehn,S. Celiakiboken om glutenintolerans. Stockholm: Förlagshuset Gothia; 2005.

73. Woodward J. Coeliac disease. Medicine. 2011;39: 173-177.

74. Lionetti E, Catassi C. New clues in celiac disease epidemiology, pathogenesis, clinical manifestations, and treatment. Int Rev Immunol. 2011;30: 219-231.

75. Kupper C. Dietary guidelines and implementation for celiac disease. Gastroenterology. 2005;128: 121-127.

76. Mazzeo T, Cauzzi S, Brighenti F, Pellegrini N. The development of a composition database of gluten-free products. Public Health Nutr. 2015;18: 1353-1357.

77. Bruins Slot I, Bremer M, Hamer R, van der Fels-Klerx H. Part of celiac population still at risk despite current gluten thresholds. Trends Food Sci Technol. 2015;43: 219-226.

78. Rose C, Howard R. Living with coeliac disease: a grounded theory study. J Hum Nutr Diet. 2014;27: 30-40. 
79. Zarkadas M, Dubois S, Macisaac K, Cantin I, Rashid M, Roberts K, et al. Living with coeliac disease and a gluten-free diet: A Canadian perspective. J Hum Nutr Diet. 2013;26: 10-23.

80. Schroeder R, Mowen T. "You Can't Eat WHAT?" Managing the Stigma of Celiac Disease. Deviant Behav. 2014;35: 456-474.

81. Ciacci C, Iavarone A, Siniscalchi M, Romano R, de Rosa A. Psychological Dimensions of Celiac Disease Toward and Integrated Approach. Dig Dis Sci. 2002;47: 2082.

82. Sverker A, Hensing G, Hallert C. 'Controlled by food'- lived experiences of coeliac disease. J Hum Nutr Diet. 2005;18: 171-180.

83. Ford S, Howard R, Oyebode J. Psychosocial aspects of coeliac disease: A cross-sectional survey of a UK population. Br J Health Psychol. 2012;17: 743757.

84. Diener E. Guidelines for National Indicators of Subjective Well-Being and Ill-Being. J Happiness Stud. 2006;7: 397-404.

85. Dimenas E, Carlsson G, Glise H, Israelsson B, Wiklund I. Relevance of norm values as part of the documentation of quality of life instruments for use in upper gastrointestinal disease. Scand J Gastroenterol 1996; Suppl 31:8-13.

86. Wu S, Wang R, Zhao Y, Ma X, Wu M, Yan X, et al. The relationship between self-rated health and objective health status: a population-based study. BMC Public Health. 2013;13: 320-320.

87. Diener,E. Kahneman,D. Helliwell,J. International Differences in WellBeing. GB: Oxford University Press; 2010.

88. Kane R. In: Breslow L, editor. Encyclopedia of Public Health. New York: Macmillan Reference USA; 2002. pp. 1003-1006.

89. Ludvigsson JF, Sellgren C, Runeson B, Långström N, Lichtenstein P. Increased suicide risk in coeliac disease-a swedish nationwide cohort study. Dig Liver Dis. 2011;43: 616-622.

90. Hallert C, Granno C, Grant C, Hulten S, Midhagen G, Strom M, et al. Quality of life of adult coeliac patients treated for 10 years. Scand J Gastroenterol. 1998;33: 933-938. 
91. Lee A, Ng D, Diamond B, Ciaccio E, Green P. Living with coeliac disease: survey results from the USA. J Hum Nutr Diet. 2012;25: 233-238.

92. Roos S, Wilhelmsson S, Hallert C. Swedish women with coeliac disease in remission use more health care services than other women: a controlled study. Scand J Gastroenterol. 2011;46: 13-19.

93. Hubley J. Patient education in the developing world -- a discipline comes of age. Patient Educ Couns. 2006;61: 161-164.

94. Albada A, Elbers E, Visser A. Patient education in Western European hospitals: A comparison of the Netherlands, Flanders and England. Patient Educ Couns. 2007;66: 4-10.

95. Leino-Kilpi H, Johansson K, Heikkinen K, Kaljonen A, Virtanen H, Salanterä S. Patient Education and Health-related Quality of Life: Surgical Hospital Patients as a Case in Point. J Nurs Care Qual. 2005;20: 307-316.

96. Strömberg A. Patient-related Factors of Compliance in Heart Failure: Some New Insights into an Old Problem. Eur Heart J. 2006;27: 379-381.

97. Friberg F, Granum V, Bergh A. Nurses' patient-education work:

Conditional factors - an integrative review. J Nurs Manag. 2012;20: 170-186.

98. Iqbal N, Morgan C, Maksoud H, Idris I. Improving Patients' Knowledge on the Relationship Between HbA1c and Mean Plasma Glucose Improves Glycaemic Control Among Persons with Poorly Controlled Diabetes. Ann Clin Biochem. 2008;45: 504-507.

99. Harwell T, Dettori N, McDowall J, Quesenberry K, Priest L, Butcher M, et al. Do Persons with Diabetes Know Their (A1C) Number? Diabetes Educ. 2002;28: 99-105.

100. Silén C, Uhlin L. Self-directed learning - a learning issue for students and faculty! Teaching in Higher Education. 2008;13: 461-475.

101. Silén C. Mellan kaos och kosmos : om eget ansvar och självständighet i lärande: Linköping : Univ.,; 2000.

102. Rideout E. Transforming nursing education through problem-based learning. Boston: Jones and Bartlett; 2001. 
103. Arvidsson S, Bergman S, Arvidsson B, Fridlund B, Tingström P. Effects of a self-care promoting problem-based learning programme in people with rheumatic diseases: A randomized controlled study. J Adv Nurs. 2013;69: 1500-1514.

104. Maudslay G. Do we all mean the same thing by problem-based learning? A review of the concepts and a formulation of the ground rules. Acad Med. 1999;74: 178-185.

105. Meleis AI. Transitions theory : middle range and situation specific theories in nursing research and practice: New York : Springer Pub; 2010.

106. Chick N, Meleis A. Transitions: A Nursing Concern. In: In Chinn P, editor. Nursing research methodology, editor. : ScholarlyCommons, 1986-0101T08:00:00Z; 1986.

107. Meleis A, Trangenstein P. Facilitating transitions: redefinition of the nursing mission. Nurs Outlook. 1994;42: 255-259.

108. Meleis A, Sawyer L, Im E, Messias D, Schumacher K. Experiencing transitions: an emerging middle-range theory. ANS. 2000;23: 12-28.

109. Roos S, Wilhelmsson S, Vulcan A, Sjöberg K, Hallert C. Bowel symptoms, self-image and comorbidity impact on well-being of women with coeliac disease. J Nurs Healthc Chronic Illn. 2011;3: 302-309.

110. Midhagen G, Hallert C. High rate of gastrointestinal symptoms in celiac patients living on a gluten-free diet: controlled study. Am J Gastroenterol. 2003;98: 2023-2026.

111. Cavanagh S, Orem D. Orem's model in action: London : Macmillan; 1991.

112. Orem DE. Nursing : concepts of practice. 4th ed: St. Louis : Mosby; 1991.

113. van Hees N, Van dD, Giltay E. Coeliac disease, diet adherence and depressive symptoms. J Psychosom Res. 2013;74: 155-160.

114. Megiorni F, Mora B, Bonamico M, Barbato M, Montuori M, Viola F, et al. HLA-DQ and susceptibility to celiac disease: evidence for gender differences and parent-of-origin effects. Am J Gastroenterol. 2008;103: 997-1003. 
115. Lovelund AA. The deviant diner: The impact of gender on the subjective experience of living with celiac disease, ProQuest Information \& Learning. 2009. Available:

http://search.ebscohost.com/login.aspx?direct=true\&db=psyh\&AN=200999220-225\&site=eds-live.

116. Whitaker J, West J, Holmes G, Logan R. Patient perceptions of the burden of coeliac disease and its treatment in the UK. Aliment Pharmacol Ther. 2009;29: 1131-1136.

117. Patton MQ. Qualitative research \& evaluation methods : integrating theory and practice : the definitive text of qualitative inquiry frameworks and options. Thousand Oaks, Calif.: Sage; 2014.

118. Beck C. The lived experience of postpartum depression: a phenomenological study. Nurs Res. 1992;41: 166-170.

119. Lopez K, Willis D. Descriptive versus interpretive phenomenology: their contributions to nursing knowledge. Qual Health Res. 2004;14: 726-735.

120. Aanstoos C, Giorgi A. Phenomenology and psychological research. Pittsburgh, Pa.: Duquesne University Press; 1985.

121. Giorgi A. The descriptive phenomenological method in psychology : a modified husserlian approach. Pittsburgh: Duquesne Univ Press; 2009.

122. Kvale S, Brinkmann S. InterViews : learning the craft of qualitative research interviewing. 2nd ed. Los Angeles: Sage Publications; 2009.

123. Bevan M. A Method of Phenomenological Interviewing. Qual Health Res. 2014;24: 136-144.

124. Giorgi A. The theory, practice, and evaluation of the phenomenological method as a qualitative research. Journal of Phenomenological Psychology. 1997;28: 235-260.

125. Giorgi A. The Descriptive Phenomenological Psychological Method. Journal of Phenomenological Psychology. 2012;43: 3-12.

126. Smith JA. Qualitative psychology: a practical guide to research methods. London: Sage; 2003. 
127. Sverker A, Östlund G, Hallert C, Hensing G. Sharing life with a glutenintolerant person - the perspective of close relatives. J Hum Nutr Diet. 2007;20: 412-422.

128. Rich S, Keim R, Shuler C. Problem-based learning versus a traditional educational methodology: a comparison of preclinical and clinical periodontics performance. J Dent Educ. 2005;69: 649-662.

129. Moust J, van Berkel H, Schmidt H. Signs of Erosion: Reflections on Three Decades of Problem-based Learning at Maastricht University. Higher Education. 2005;50: 665-683.

130. Tingström P, Kamwendo K, Bergdahl B. Effects of a problem-based learning rehabilitation programme on quality of life in patients with coronary artery disease. Eur J Cardiovasc Nurs. 2005;4: 324-330.

131. Kamwendo K, Tingstrom P, Bergdahl B, Svensson E. Effect of problembased learning on stages of change for exercise behaviour in patients with coronary artery disease. Physiother Res Int. 2004;9: 24-32.

132. Wikblad K, Leksell J, Smide B. "I'm the boss" testing the feasibility of an evidencebased patient education programme using problem based learning. Eur Diabetes Nursing. 2004;1: 13-17.

133. Boud D, Feletti G. The challenge of problem-based learning. 2nd ed. London: Kogan Page; 1997.

134. Wenger N, Mattson M, Furberg C, Elinson J. Assessment of quality of life in clinical trials of cardiovascular therapies. Am J Cardiol. 1984;54: 908-913.

135. Glise H, Hallerback B, Johansson B. Quality of Life assessments in the evaluation of gastroesophageal reflux and peptic ulcer disease before, during and after treatment. Scand J Gastroenterol Suppl. 1995;208: 133-135.

136. Dimenas E, Glise H, Hallerback B, Hernqvist H, Svedlund J, Wiklund I. Well-being and gastrointestinal symptoms among patients referred to endoscopy owing to suspected duodenal ulcer. Scand J Gastroenterol. 1995;30: 1046-1052. 
137. Wiklund I, Carlsson J, Vakil N. Gastroesophageal Reflux Symptoms and Well-Being in a Random Sample of the General Population of a Swedish Community. Am J Gastroenterol. 2006;101: 18-28.

138. Houser J. Nursing research : reading, using, and creating evidence. 3rd ed: Sudbury, Mass: Jones \& Bartlett Learning,; 2015.

139. Krippendorff K. Content analysis: an introduction to its methodology. 3rd ed. Thousand Oaks, Calif; London: Sage; 2013.

140. Krippendorff K. Content analysis : an introduction to its methodology. Beverly Hills: Sage Publications; 1980.

141. WMA. Declaration of Helsinki - Ethical Principles for Medical Research Involving Human Subjects. . 2013. Available:

http://www.wma.net/en/30publications/10policies/b3/index.html.

142. Grove S, Burns N, Gray J. The practice of nursing research : appraisal, synthesis, and generation of evidence. 7th ed: St. Louis, Mo. : Elsevier/Saunders,; 2013.

143. Lincoln YS, Guba EG. Naturalistic inquiry. Beverly Hills, Calif.: Sage; 1985.

144. Guba E, Lincoln Y. Fourth generation evaluation: Newbury Park, Calif : Sage,; 1989.

145. Revicki D, Leidy N, Howland L. Evaluating the psychometric characteristics of the Psychological General Well-Being Index with a new response scale. Qual Life Res. 1996;5: 419-425.

146. Dimenas E, Glise H, Hallerback B, Hernqvist H, Svedlund J, Wiklund I. Quality of life in patients with upper gastrointestinal symptoms. An improved evaluation of treatment regimens? Scand J Gastroenterol. 1993;28: 681-687.

147. Najafi Ghezeljeh T, Yadavar Nikravesh M, Emami A. Coronary heart disease patients transitioning to a normal life: perspectives and stages identified through a grounded theory approach. J Clin Nurs. 2014;23: 571-585.

148. Najafi Ghezeljeh T, Emami A. Strategies for recreating normal life: Iranian coronary heart disease patients' perspectives on coping strategies. J Clin Nurs. 2014;23: 2151-2161. 
149. Nilsen G, Anderssen N. Struggling for a normal life: Work as an individual self-care management strategy among persons living with nonmalignant chronic pain. Work. 2014;49: 123-132.

150. Badenhorst J. Coeliac disease. S Afr Fam Pract. 2014;56: 31-34.

151. Taylor E, Dickson-Swift V, Anderson K. Coeliac disease: the path to diagnosis and the reality of living with the disease. J Hum Nutr Diet. 2013;26: 340-348.

152. LeDoux J. Evolution of human emotion: a view through fear. Prog Brain Res. 2012;195: 431-442.

153. Schumacher K, Meleis A. Transitions: a central concept in nursing. Image J Nurs Scholarsh. 1994;26: 119-127.

154. Olsson C, Lyon P, Hörnell A, Ivarsson A, Sydner Y. Food that makes you different: The stigma experienced by adolescents with celiac disease. Qual Health Res. 2009;19: 976-984.

155. Thompson T, Peräaho M, Collin P, Kaukinen K, Mäki M. Contaminated oats and other gluten-free foods in the United States. J Am Diet Assoc. 2005;105: 348-349.

156. Groff A. Hegemonic masculinity. Salem Press Encyclopedia. 2013: 1.

157. Gibbs L. Applications of masculinity theories in a chronic illness context. Int J Mens Health. 2005;4: 287-300.

158. Williams B, Pace AE. Problem based learning in chronic disease management: A review of the research. Patient Educ Couns. 2009;77: 14-19.

159. Ringstrom G, Storsrud S, Posserud I, Lundqvist S, Westman B, Simren M. Structured patient education is superior to written information in the management of patients with irritable bowel syndrome: a randomized controlled study. Eur J Gastroenterol Hepatol. 2010;22: 420-428.

160. Wikman A, Wardle J, Steptoe A. Quality of life and affective well-being in middle-aged and older people with chronic medical illnesses: a cross-sectional population based study. PLoS One. 2011;6: e18952. 
161. Zordan RD, Juraskova I, Butow PN, Jolan A, Kirsten L, Chapman J, et al. Exploring the impact of training on the experience of Australian support group leaders: current practices and implications for research. Health Expect. 2010;13: 427-440.

162. Hepworth M, Harrison J. A Survey of the Information Needs of People with Multiple Sclerosis. Health Informatics Journal. 2004;10: 49-69.

163. Hjelmfors L, Abrandt Dahlgren M, Kärner A, Tingström P. Problem-based learning used in the context of cardiac rehabilitation: different scenes and different roles. Studies in Continuing Education. 2014;36: 218-232.

164. Dowd A, Tamminen K, Jung M, Case S, McEwan D, Beauchamp M. Motives for adherence to a gluten-free diet: a qualitative investigation involving adults with coeliac disease. J Hum Nutr Diet. 2014;27: 542-549.

165. Cohen S. Social relationships and health. Am Psychol. 2004;59: 676-684.

166. Yalom ID, Leszcz M. The theory and practice of group psychotherapy (5th ed.). New York, NY, US: Basic Books; 2005.

167. Laughlin C, Beisel M. Evolution of the Chronic Care Role of the Registered Nurse in Primary Care. Nurs Econ. 2010;28: 409-414.

168. Davies N. Improving Self-management for Patients with Long-term Conditions. Nursing Standard. 2010;24: 49-56.

169. Aanstoos C, Giorgi A. Phenomenology and psychological research. Pittsburgh, Pa.: Duquesne University Press; 1985.

170. Chan Z, Fung Y, Chien W. Bracketing in phenomenology: Only undertaken in the data collection and analysis process? Qualitative Report. 2013;18: 1-9.

171. Polit, Denise F., Hungler,Bernadette P.,. Nursing research : principles and methods. Philadelphia: Lippincott; 1999.

172. Altman DG. Practical statistics for medical research. London; New York: Chapman and Hall; 1991. 
173. Polit, Denise F., Beck,Cheryl Tatano. Nursing research : generating and assessing evidence for nursing practice. 9th ed. Philadelphia: Wolters Kluwer, Lippincott Williams \& Wilkins; 2012.

174. Balakrishnan N. Methods and applications of statistics in clinical trials. Volume 1. . 2014. 



\section{Papers}

The articles associated with this thesis have been removed for copyright reasons. For more details about these see:

http://urn.kb.se/resolve?urn=urn:nbn:se:liu:diva-122382 